\title{
Nature of the Kergelen Plateau and Its Place in the Structural Plan of the Southern Sector of the Indian Ocean
}

\author{
V. K. Illarionov ${ }^{a, *}$, A. N. Boyko ${ }^{a, * *}$, A. Yu. Borisova ${ }^{b, c, * * *}$, and D. A. Ilyinsky ${ }^{d, e, * * * *}$ \\ ${ }^{a}$ Schmidt Institute of Physics of the Earth, Russian Academy of Sciences, Moscow, 123242 Russia \\ ${ }^{b}$ Institute of Geological and Environmental Sciences in Toulouse, Toulouse, 31400 France \\ ${ }^{c}$ Faculty of Geology, Moscow State University, Moscow, 119991 Russia \\ ${ }^{d}$ Shirshov Institute of Oceanology, Russian Academy of Sciences, Moscow, 117218 Russia \\ e Individual Entrepreneur Ilynsky A.D., Moscow, Russia \\ *e-mail:vkillar@mail.ru \\ **e-mail:boyko@ifz.ru \\ ***e-mail: anastassia.borisova@get.omp.eu \\ ****e-mail: dilinskiy61@mail.ru
}

Received July 6, 2021; revised August 13, 2021; accepted August 16, 2021

\begin{abstract}
The morphostructural characteristics of the main taxa of southern Indian Ocean, such as the Del Cano-Crozet, Conrad, and Kerguelen plateaus, are given based on structural-tectonic analysis. A depth map of the acoustic basement of the eastern part of the Afro-Antarctic megadepression is first built using the digitized NGDS database on the thickness of the sedimentary cover of the Indian Ocean, which is available on the Internet. A critical analysis of deep seismic sounding (DSS) data on the Kerguelen plateu hs been performed. A geochemical analysis of more than 100 samples of basalts, acidic rocks, and rocks of sedimentary origin, collected on the islands of the Kerguelen archipelago and raised by dredging and deep-sea drilling from the Kerguelen and Conrad plateaus, is carried out. The study has shown that the plateaus resemble the Madagascar Ridge in terms of morphostructure and a number of other features. It is concluded that these flat-topped horst massifs were the part of the "structural bridge" that connected Madagascar and the eastern part of mainland Antarctica no later than the Paleogene. A proposed alternative version of the geological interpretation of the deep seismic data states that the plateau has a relatively homogeneous structure along the strike, including a thick (at least 15-km) layer of continental crust. An analysis of the depth map of the acoustic basement made it possible to identify the depocenters of the relatively isolated Enderby, Shackleton and Labuan basins framing the Kerguelen Plateau on the southern side. The paragenetic connections of the Kerguelen Plateau with the basins indicate that the isolation of the Kerguelen Plateau from East Antarctica and the formation of the modern structure of the region began in the Late Cretaceous and ended with the last phase of tectonic activation in the Late Miocene-Pliocene. The results of geochemical analysis show that the geochemical and petrological anomalies of the plateau and islands are associated with the crust, and not with the mantle contamination, as well as with the continental nature of the Kerguelen Plateau.
\end{abstract}

Keywords: aseismic ridge, oceanic plateau, depression depocenter, differentiated tectonic movements, domeshaped structure, hot spot, Kerguelen Plateau

DOI: $10.1134 / \mathrm{S} 0001433821100054$

\section{INTRODUCTION}

According to plate tectonics, large geodynamic and tectonomagmatic events such as the breakup of East Gondwana and the Greater India northward flight took place in the southern Indian Ocean (Johnson et al., 1976). This so-called flight was associated with high spreading rate, the estimated value of which reached more than $20 \mathrm{~cm} /$ year (Moeremans and Singh, 2014). After that, the structural map of midoceanic ridges had changed and high spreading rates gave way to ultraslow growth of the ridges (Cande and
Mutter, 1982). A large igneous province (LIP) was formed. The breakup of this formation into two parts, the West Australian Ridge and the Kerguelen Plateau, which took place in the Eocene (Mutter and Cande, 1983), initiated a 1200-km drift of the Kerguelen Plateau from the spreading axis to the southwestern flank of the middle Australian-Antarctic Ridge, the area where India was once located. Three hot spots, Kerguelen, Marion, and Crozet, and three ridges genetically related to them, the East Indian Ridge, the $85^{\circ} \mathrm{E}$ Ridge, and the Chagos-Lakkadiv Ridge, had arisen in 
the southern sector (Curray and Moor, 1974). The study of these issues in terms of plate tectonics is of great interest, and it is quite obvious that it should be continued.

Goals and objectives. This paper is focused on the morphostructural, geological, geophysical, and geochemical features of the Kerguelen Plateau and on identifying its paragenetic relations with adjacent structures without regard to the essentials of plate tectonics. To address these issues, we constructed a map of the acoustic basement, taking into account the NGDS digital data on the thickness of the sedimentary cover in the Indian Ocean. The results made it possible to establish the structural features of the acoustic basement hidden by the sedimentary cover and, for the first time, reveal the depocenters of relatively isolated basins adjacent to the plateau. In addition, the geochemical analysis of more than 100 samples of basalt and sedimentary rocks recovered from deep-sea drilling, as well as samples of acidic rocks collected during the MD 48 and MD 109 cruises of the R/V Marion Dufresne, was carried out. Particular attention was paid to the study of available materials from the Internet and published sources. The results of a generalization of the obtained and compiled data made it possible to establish the peculiarities of the geological structure of the Kerguelen Plateau and identify the main features of the Mesozoic-Cenozoic stage of the region evolution.

State of exploration of the Kerguelen Plateau. The morphostructure of the Kerguelen Plateau is wellstudied. It is uniformly covered by a network of seismic profiles, made by continuous seismic profiling and common midpoint methods; detailed maps of the magnetic and gravity fields have been compiled. Deep seismic soundings were carried out in the northern, central, and southern parts of the plateau, as well as on Elan Bank and in the adjacent Enderby Basin (Recg and Charvis, 1986; Recg et al, 1990; Operto and Charvis 1995, 1996; Kónnecke et al., 1997; Charvis and Operto, 1999).

Twenty deep-water wells have been drilled on the Kerguelen Plateau and in the adjacent areas. Six wells, 736-738 and 744-746, were drilled in 1987-1988 during the 119th cruise of the R/V Joides Resolution (wells 739-743 are located in Prydz Bay); in 1988, five wells, 747-751, were drilled during the 120th ODP cruise. Six wells, 1135-1140, were drilled during the 183rd IODP cruise in 1998-1999; wells 1165-1167 were drilled in 2000 during the 188th IODP cruise to the Commonwealth Sea and Prydz Bay. Geochemical analysis of the basalts of the Kerguelen Plateau, recovered by drilling, showed that they are contaminated with the material of the continental crust. However, these results have not been unambiguously assessed, since they could be interpreted either in favor of the continental nature of the basement or the oceanic nature of the plateau, with the mantle source heavily contaminated with continental matter. The representative collection of rocks samples of both basic and acidic composition was collected by dredging from bedrock outcrops and by sampling on the islands; however, an examination of these sample does not give a definitive answer to the question of the nature of the Kerguelen Plateau.

\section{Some Critical Remarks on Plate Tectonic Modeling of the Southern Indian Ocean in Respect to the Nature of the Kerguelen Plateau}

The nature of the Kerguelen Plateau has been the subject of a long discussion which is still not fully resolved. In 1960-1970, most distinguished researchers preferred the continental nature of the plateau (Wilson, 1963; Dietz, 1966; Heezen and Tharp, 1966; Francis and Raitt, 1967; Laughton et al., 1970; Dietz and Holden, 1971; Schlich and Patriat, 1971; Schlich et al., 1971; Pushcharovsky and Bezrukov, 1973; Hedge et al., 1973; Upton, 1983; Udintsev, 1989; etc.). In support of their arguments, the authors of these works gave the following arguments: (1) the discovery of granite pluton with an area of $350 \mathrm{~km}^{2}$ on Kerguelen Island (Nougier and Lameyre, 1972); (2) the presence of granite and metamorphic rocks inherent in the continental crust in the basement of the plateau (Ramsay et al., 1986); and (3) a crust thickness $25 \mathrm{~km}$, which is anomalously high for oceanic plateaus, corresponding more to a crust of the subcontinental type. It was assumed that there is a structural connection between the Kerguelen Plateau and the Gaussberg Volcano, socalled Kerguelen-Gaussberg Rücken (Vanney, Johnson, 1982), and that together they form a KerguelenGaussberg Ridge, a continental fragment remained after the collapse of Gondwana (Watkins et al., 1974; Schlich, 1983; etc.).

As the popularity of the theory of plate tectonics increased, the question of the nature of the Kerguelen Plateau became more acute. The problem was there was no place for such a large fragment of the continental crust like the Kerguelen-Gaussberg Ridge in the new reconstruction of Gondwana. In order to solve the problem of this "extra puzzle piece," supporters of plate tectonics attributed Kerguelen to the oceanic plateau, endowing it with a complex history of geodynamic development. The story of Elan Bank is a prime example in this regard. When deep-sea drilling provided irrefutable evidence of its continental nature, it was declared a microcontinent, a fragment of the Indian subcontinent that broke away during the spreading axis jump (Wallace et al., 2002) and joined the Kerguelen Plateau as a result of horizontal drift. In the Eocene, the Kerguelen, together with the Elan Bank, broke away from the West Australian Ridge and, having overcome a distance of $1200 \mathrm{~km}$ as a result of spreading, moved to the southwestern flank of the Australian-Antarctic Ridge (Kent et al., 2002; Borissova et al., 2003; Gibbons et al., 2013; 
(a)

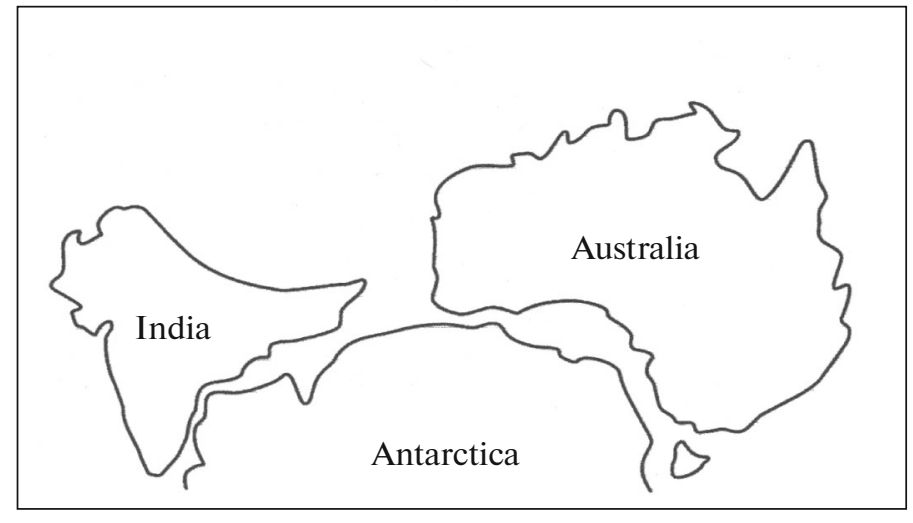

(c)

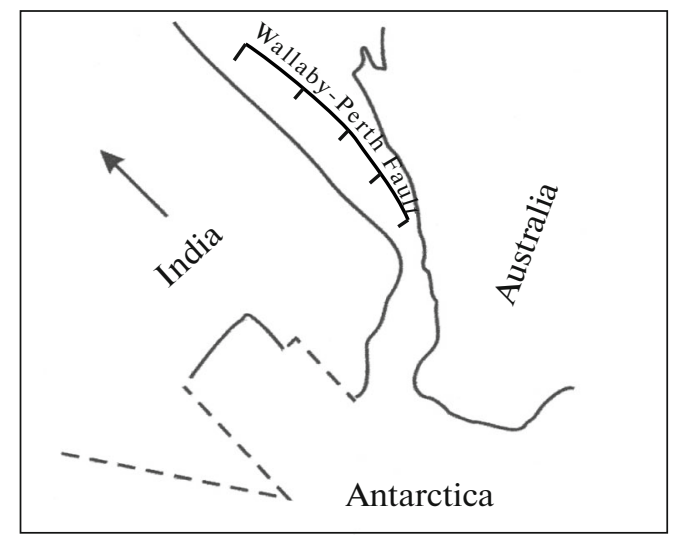

(e)

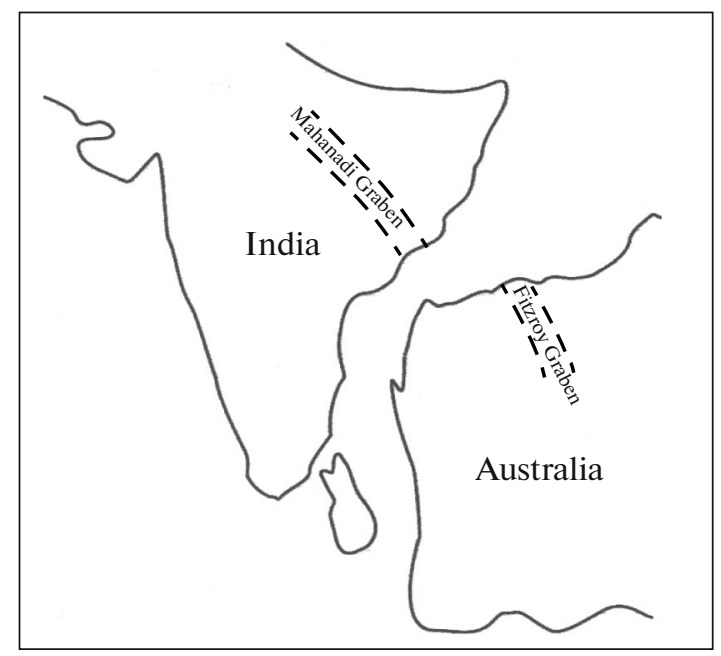

(b)

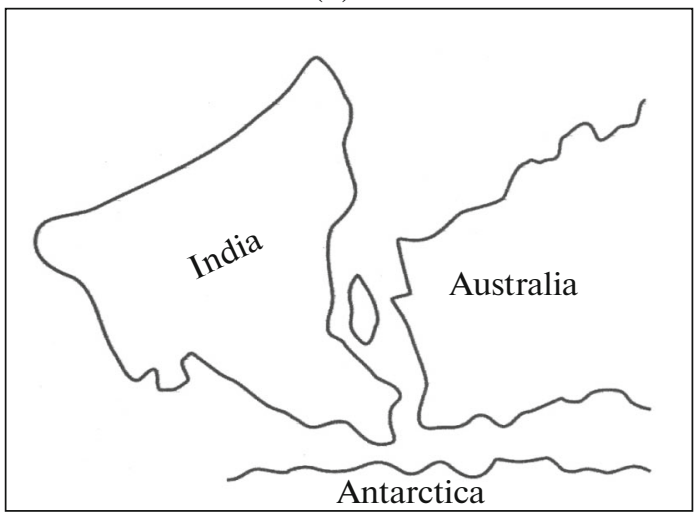

(d)

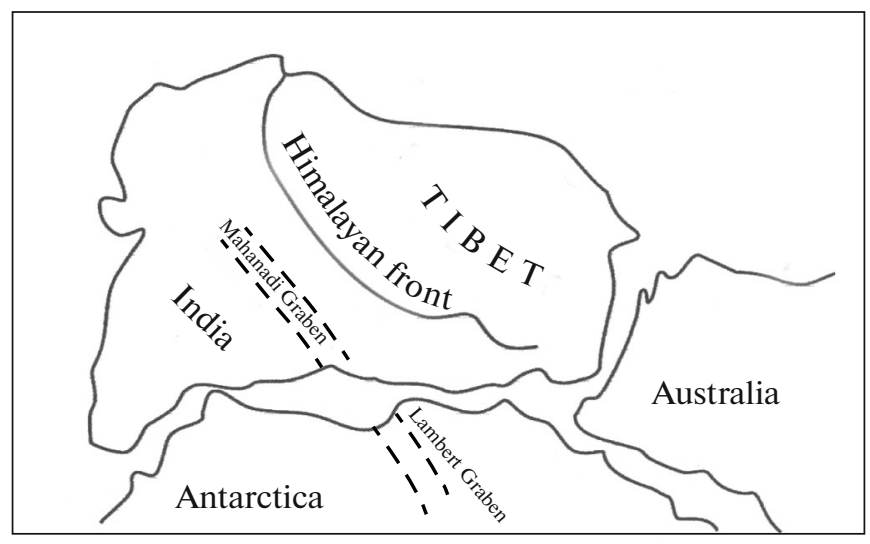

(f)

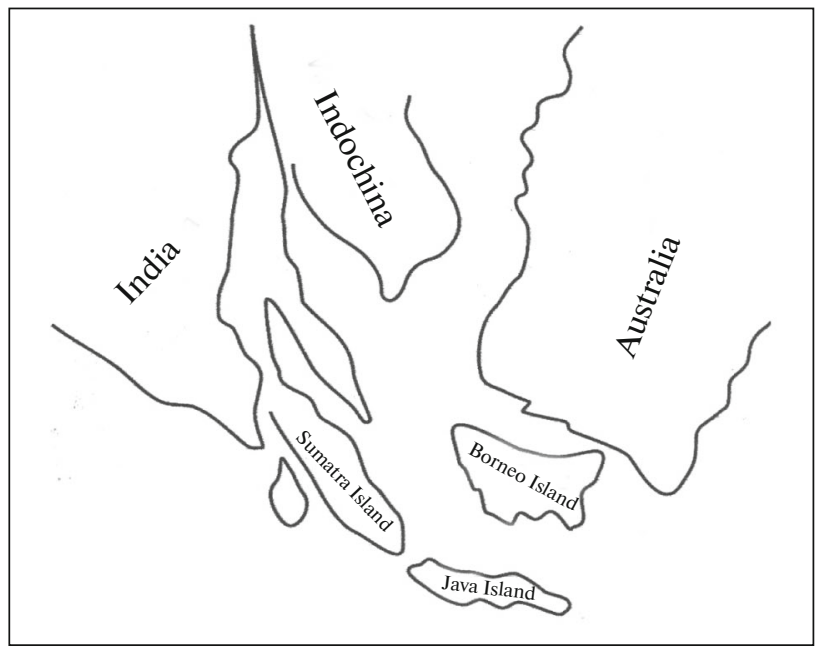

Fig. 1. Models of plate tectonic reconstructions of the eastern part of Gondwana: (a) after (Smith and Hallem, 1970), (b) after (Veevers et al., 1975), (c) after (Markl, 1974), (d) after (Falvey, 1972), (e) after (Crawford, 1969; Sastri et al., 1981; Mohanty, 2012), and (f) after (Ridd, 1971).

etc.). As follows from the above, the Elan bank is a "foreign body" in relation to the Kerguelen Plateau. As for the plateau as a whole, from the point of view of plate tectonics, it appears to be a structural-mag- matic conglomerate consisting of two or three continental blocks (terranes), a fragment of a magmatic province, and a hot spot (Borissova et al., 2003; Leichenkov et al., 2018; etc.). 
Although the problem with the oceanic origin of Kerguelen thus appears to be solved, the question of the initial position of the Indian subcontinent in terms of plate tectonic modeling remained open. In other words, an algorithm that would determine the place of this puzzle piece in the general scheme of the Gondwana continents has not yet been created (see Fig. 1 for some models of plate tectonic reconstructions).

Currently, the most popular are two models that differ in the position of the Indian subcontinent. One, based on the reconstruction of Ahmand, was developed in the works (Crawford, 1969; Sastri et al., 1981; Mohanty 2012; etc.) (see Fig. 1e). In this model, not only the outlines of the coastlines of East India and Northwestern Australia, but also the morphostructure of the continental margins itself are in good agreement. Thus, the eastern continental slope of India, which, according to many prominent researchers, is the steepest in the world (Udintsev, 1972), can correspond as a mirror image to the large-amplitude scarp of the Wallaby-Perth lineament, which extends along the northwestern coast Australia (see Fig. 1c). In addition, there is a good structural alignment between the Mahanadi Graben (India) and the Fitzroy Graben (Australia) (see Fig. 1e). This reconstruction is also confirmed by the results of a comparative analysis of the geology of India and Australia obtained by Mohanty (2012). His studies of the Neoproterozoic supercontinent Rodinia showed that the Dharwar Craton in South India and the Yilgarn Craton in Western Australia were closely located in the Paleoproterozoic and experienced a number of common geological events in the course of their evolution. Thus, the Satpura Mountains in India experienced three episodes of orogeny $(2100-1900,2185$, and $1650 \mathrm{Ma}$ BP) with the development and closure of basins. The Capricorn Orogen in Western Australia also experienced three episodes of orogeny (21001950,2180 , and $1650 \mathrm{Ma} \mathrm{BP}$ ), which were also associated with the development and closure of the basins. This similarity suggests common evolution of the cratons of India and Western Australia in the Paleoproterozoic (Mohanty, 2012).

Another model was created based on the reconstruction by Smith and Hallem (1970) and supplemented by Falvey (1972) (see Figs. 1a, 1d). The latter included the Tibet Plateau to the India Subcontinent and thus successfully filled the empty space between India and Australia. Later, the concept of Greater India became widely used in plate tectonic reconstruction (Johnson et al., 1976; Gibbons et al., 2013; etc.). This model provides a good agreement of the outlines of the East India and East Antarctica coastlines along the $1.0-\mathrm{km}$ depth line. It is confirmed by good alignment of the Mahanadi (India) and Lambert (East Antarctica) grabens (see Fig. 1d) on the map, as well as by the similarity of metamorphic rocks of the Archean granulite facies, which are involved both in the East Ghat Belt of India and East Antarctica
(Fedorov et al., 1982). This reconstruction maintains a good alignment of the coastlines, but does not take into account the structural features of the eastern continental margin of India, which has a characteristic Barisal basement ledge, jutting into the Bay of Bengal. In addition, the southern tip of the Indian subcontinent continues structurally towards the Central Basin in the form of a Comorin Ridge, the southern part of which, like the Barisal uplift, is overlain by a thick sedimentary cover of the Bengal alluvial fan (Illarionov et al., 2016). These structural features exclude the possibility of convergence of continents to the distance that was specified in the modeling, which, of course, should be taken into account when creating new reconstructions.

\section{Structure of the Southern Indian Ocean and Morphostructural Features of its Main Taxa}

The southern sector of the Indian Ocean resembles a triangle formed by the converging branches of the Indian Mid-Oceanic Rifting System. Its northwestern side is the West Indian Ridge (WIR). The northeastern side is formed by two segments of the mid-ocean ridge: the Central Indian Ridge and the AustralianAntarctic Rise, connected via the Saint-PaulAmsterdam horst massif. The base of the triangle on the southern side is the continental margin of the ancient East Antarctica Platform, along which the African-Antarctic megadepression extends from west to east, with the western part extending beyond the southern sector. Its maximum depth in the study area $(5.6 \mathrm{~km})$ is located northeast of the Gunnerus Ridge. The eastern closure of this depression is formed by the Enderby Basin, with depths not exceeding $4.6 \mathrm{~km}$; its formation is associated with the separate depocenter. The apex of the triangle falls into the Crozet Basin, which encompasses a closed 5.0-km isobath, the maximum depth being $5.8 \mathrm{~km}$ (Figs. 2, 3a).

Unlike the basins located on opposite sides of the triangle of the southern Indian Ocean, the main positive structures are grouped in its central part. These include the Del Cano-Crozet Plateau, the Conrad Plateau, and the Kerguelen Plateau (see Figs. 2, 3a).

The Del Cano-Crozet Plateau. is a large block structure with rectilinear eastern and southern slopes, which form a rectangular ledge, clearly expressed in the relief by the contours of the 3.0-, 3.5-, and $4.0-\mathrm{km}$ isobaths. Structurally, the ledge faces the northern tip of the Kerguelen Plateau. The northwestern side of the plateau borders with the riftogenic West Indian Ridge for over $1000 \mathrm{~km}$ (see Fig. 3). One characteristic feature of WIR is numerous submeridional faults breaking it into relatively narrow blocks.

Elevated blocks of the central part of the WIR were surveyed using a manned underwater vehicle (Ivanov and Vakaryuk, 1991; Lomakin and Ivanov, 2012). It was found that they have a tectonic structure. Relict 


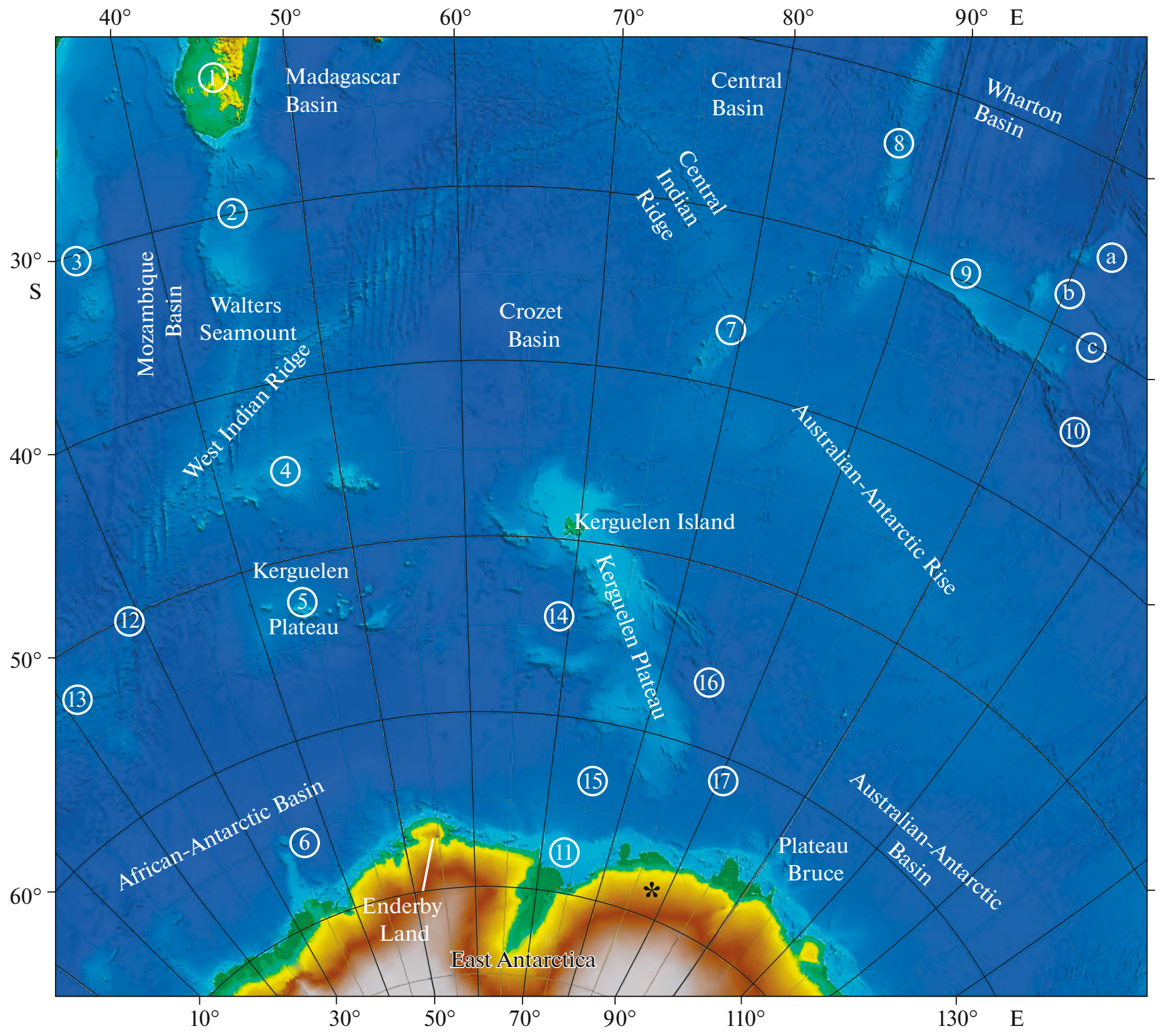

Fig. 2. Bathymetric map of the southern Indian Ocean. Lambert projection numbers in circles: (1) Madagascar Island, (2) Madagascar Ridge, (3) Mozambique Plateau, (4) Del Cano-Crozet Plateau, (5) Konrad plateau, (6) Gunnerus Ridge, (7) SaintPaul-Amsterdam Plateau, (8) East Indian Ridge, (9) West Australian Ridge, (10) Diamantina Trench, (11) Prydz Bay, (12) Andrew Bane Fault, (13) Southwest Indian Ridge, (14) Valdivia Plain, (15) Enderby Basin, (16) Labuan Basin, and (17) Shackleton Basin. (a-c) Domed structures composed of granite-gneiss rocks: (a) Batavia dome, (b) Gulden Draak dome, and (c) Udintsev dome. Asterisk indicates Gaussberg volcano.

Fig. 3. (a) Bathymetric map of the study area (Lambert projection); (b, d) bathymetric and (c, e, f) seismoacoustic sections. (a) (1) Obi Bank, (2) Lena Bank, (3) Marion Dufresne horst block, (4) volcanic islands ((4a) Marion and (4b) Prince Edward), (5) drifts, (6) Kerguelen Fault, (7) Williams Ridge, (8) Umitaka-Maru Ridge, (9) Skif Bank, (10) Elan Bank, (11) Banzare Bank, (12) the volcanic Possession Island, (13) Discovery Fault, and (14) Andrew Bane Fault. (Pr 6) Profile of the DSS AWI-20070200, (Pr 7) profile of the DSS AWI-20070100, and (4.0) depth marks, km. (b) Submeridional bathymetric profile (Profile 1 in Fig. 3a) characterizing the structure of the southern sector of the Indian Ocean. The numbers on the profile indicate (1) Gunnerus Ridge, (2) the eastern part of the African-Antarctic megadepression, (3) Conrad Plateau, (4) sublatitudinal passage, (5) Del CanoCrozet Plateau, and (6) Crozet Basin. (c) Fragment of a seismoacoustic section along the RC 0802 profile (R/V Robert Conrad, 1964) (Profile 2 in Fig. 3a). The numbers on the profile indicate (1) Valdivia Plain, (2) Elan Bank, (3) Kerguelen Plateau, (4) Williams Ridge, and (5) margin of the Australian-Antarctic Rise. (d) Bathymetric profile crossing the "structural wall" between Kerguelen and the Antarctic continent (Profile 3 in Fig. 3a). (e) Fragment of seismoacoustic profile RC 1705 (R/V Robert Conrad, 1974) characterizing the structure of the Discovery Fault (Profile 4 in Fig. 3a). (f) Fragment of seismoacoustic profile RC 1705 characterizing the structure of the passage between the Crozet Plateau and the Kerguelen Plateau (Profile 5 in Fig. 3a). 
(a)

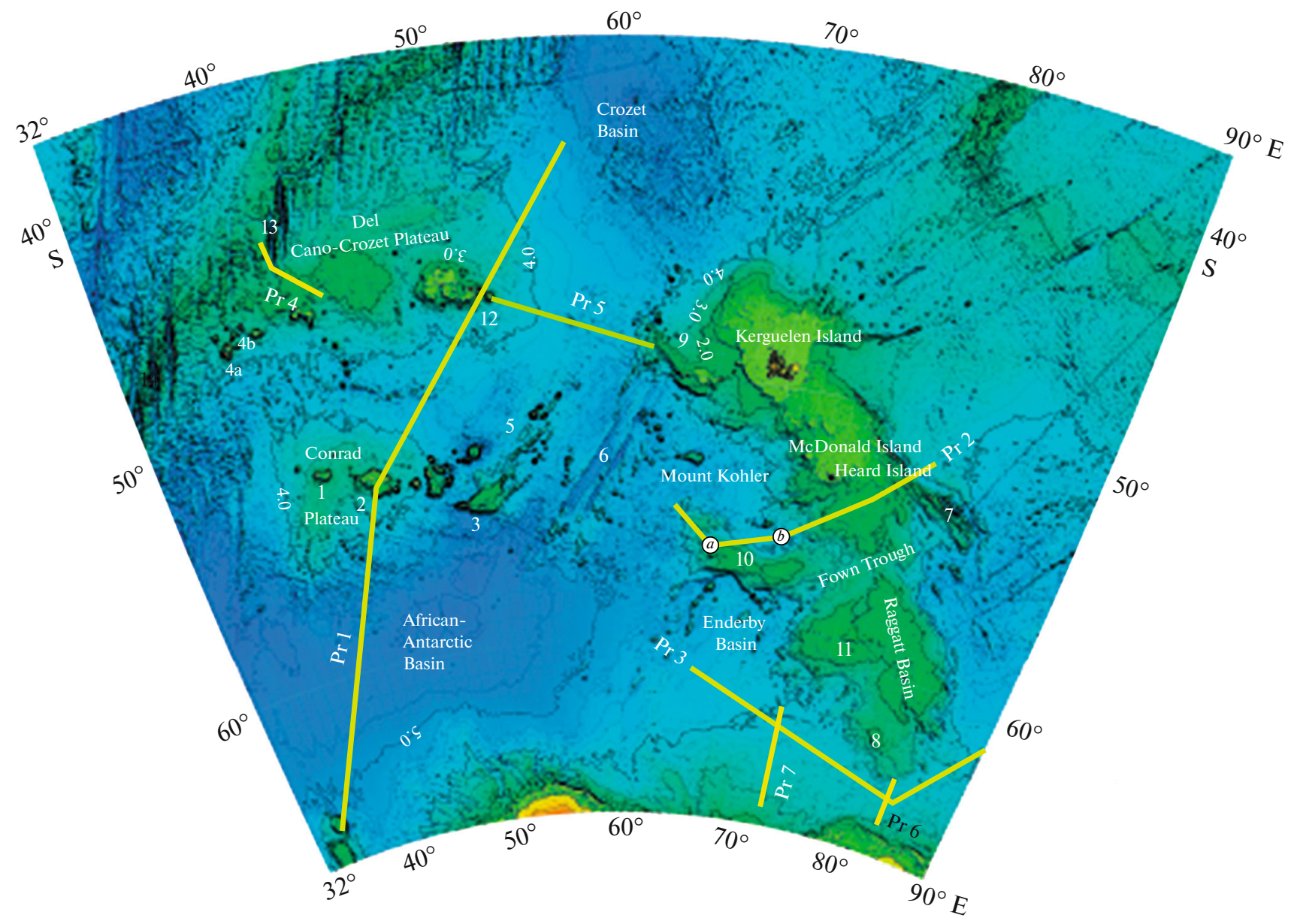

$41^{\circ} 41^{\prime} \mathrm{S}$

$56^{\circ} 42^{\prime} \mathrm{E}$

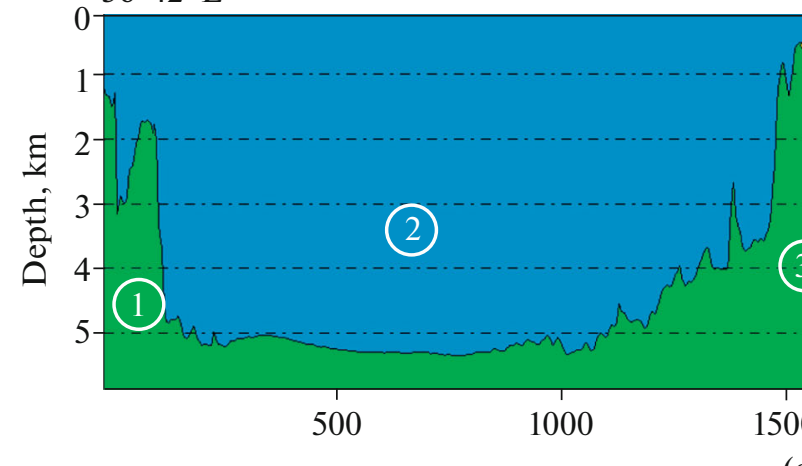

(b)

$65^{\circ} 56^{\prime} \mathrm{S}$

$33^{\circ} 36^{\prime} \mathrm{E}$

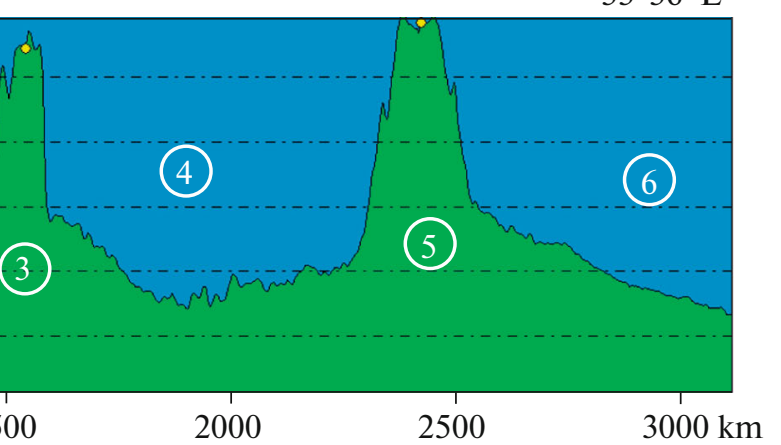

(c)

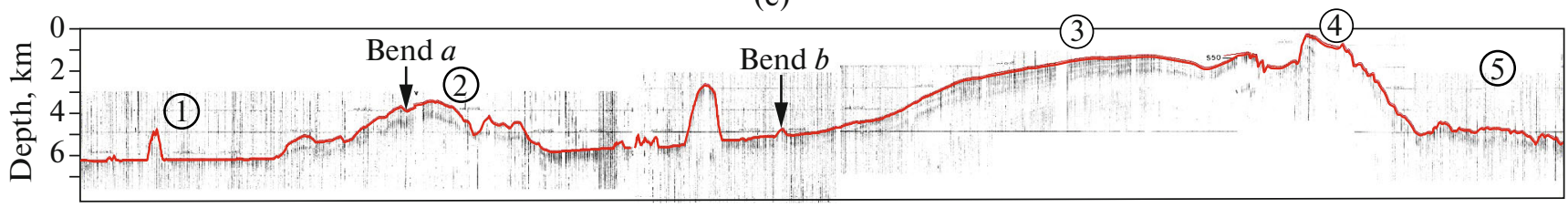




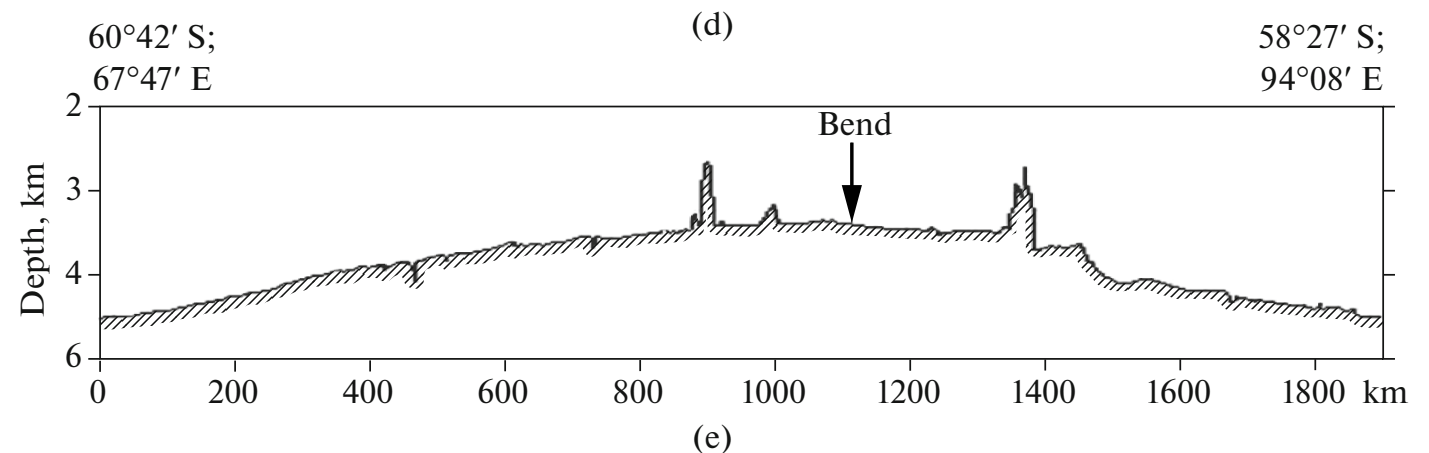

(e)

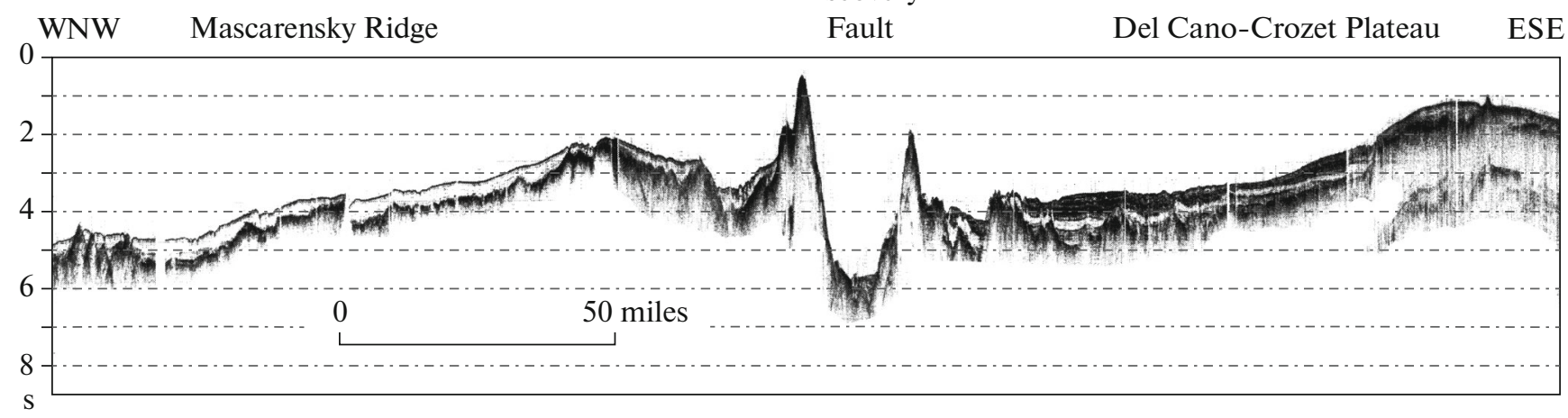

(f)

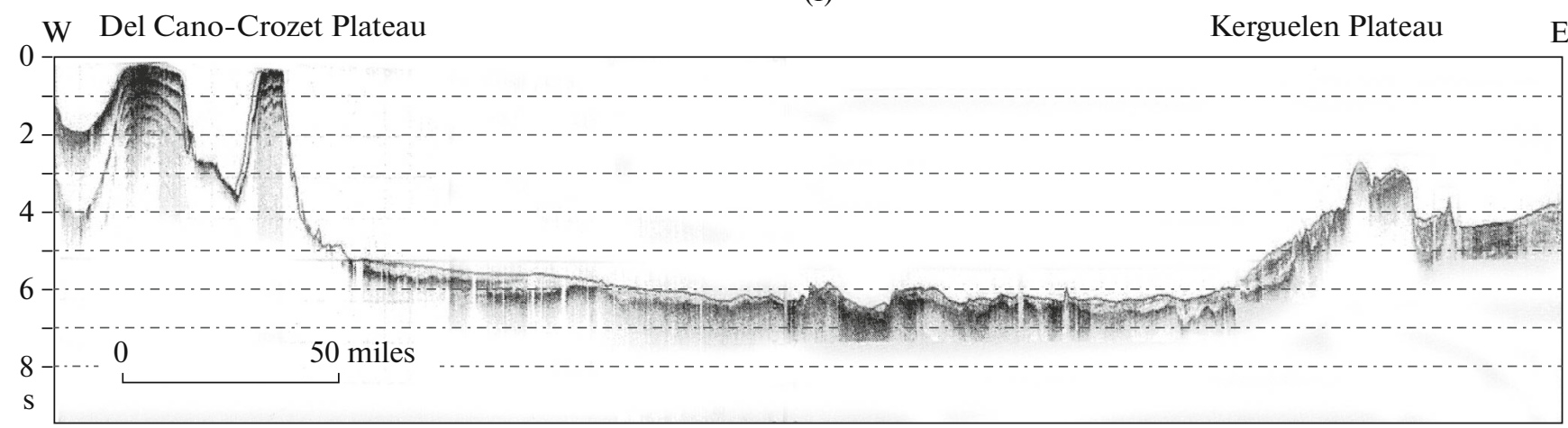

Fig. 3. (Contd.)

abrasion, erosion, and karst forms have been identified on the slopes of the blocks. One peak with a minimum elevation of $150 \mathrm{~m}$ has a multilevel system of terraces. The lower terrace, located at a depth of $1000 \mathrm{~m}$, indicates the elevation of this peak above sea level during the subaerial stage of WIR evolution.

The most extended faults of the riftogenic system penetrate deeply into the Del Cano-Crozet Plateau, which indicates their superimposed nature. The large Prince Edward Fault frames the plateau from the southwestern side (see Fig. 3a). An analysis of the morphological structure of the area using a bathymetric map (see Fig. 3a) and the seismoacoustic section crossing the Discovery Fault (see Fig. 3e) indicates that the fault is formed by parallel ridges of deep protrusions, or a chain of volcanic edifices, separated by a deep $V$-shaped trench. The fault separates the Mada- gascar Ridge from the Del Cano-Crozet Plateau. As can be seen from Fig. 3e, the layers of the sedimentary cover and the acoustic basement in the part of the plateau adjacent to the fault are homogeneous along the strike and are disturbed by a system of small faults. The faults are complicated by postsedimentary folding, caused by intrusion of small dikes into sedimentary layers. Morphologically, the plateau is divided into two parts, the Del Cano Plateau and the Crozet Plateau, both their summits being delimited by a $2.0-\mathrm{km}$ isobath. The conditional morphological boundary between them is an erosion trench with a relative depth of 500-900 m. On both sides of the trench there are the summits of deep-water canyons, developed on the southern and eastern slopes of the plateau.

There is an archipelago in the eastern part of the Crozet Plateau that includes six volcanic islands and 
several smaller rocks. The largest Possession Island rises to $1050 \mathrm{~m}$ above sea level. In the western part of the Del Cano Plateau, there are two small volcanic islands, Prince Edward and an active volcano (Marion), the last eruption of which was observed in 2004. The latter is located $20 \mathrm{~km}$ southwest of the first. Their heights are 670 and $1230 \mathrm{~m}$ above sea level and their areas are 45 and $290 \mathrm{~km}^{2}$, respectively (see Fig. 3a).

The Del Cano-Crozet Plateau is separated from the northern end of the Kerguelen Plateau by a submeridional passage, which on the sublatitudinal profile looks like an extended saddle with depth of $4.5-4.7 \mathrm{~km}$. The profile shows that the formation of this trough is associated with the subsidence of the edge blocks of both plateaus (see Fig. 3f). The morphological feature of the passage is fluvial-accumulative ridges (drifts) oriented north-northeast. They are formed by sediments brought by the northern branch of the bottom Antarctic circumpolar current, which goes past Kerguelen Island from the north (Roguet et al., 2009). The largest drifts of Crozet and Ob' extend for 200250 km (Udintsev, 1989) (see Fig. 3a).

Conrad Plateau. is characterized by a number of common morphostructural features, with the Del Cano-Crozet Plateau located to the north and separated from the Conrad Plateau by a sublatitudinal passage with depths of 4.5-4.8 km. The plateau has isometric shape and angular outlines and is framed by isobaths of $3.0,3.5$, and $4.0 \mathrm{~km}$. Its structure also contains sedimentary layers homogeneous along the strike, composed of consolidated ancient sedimentary rocks. The plateau has an erosion-denudation surface and is practically devoid of young sediments.

One characteristic feature of the Conrad Plateau are two large flat-topped horst outliers carrying $\mathrm{Ob}$ ' (depth $230 \mathrm{~m}$ ) and Lena (depth $251 \mathrm{~m}$ ) seamounts. A separate large horst block, Marion Dufresne, $400 \times$ $180 \mathrm{~km}$ in size and with the flat top, is located to the east of the plateau at a depth of less than $1 \mathrm{~km}$ (see Fig. 3a). A geochemical analysis of the samples of ultra-alkaline lavas that raised from the surface of the $\mathrm{Ob}^{\text {' and }}$ Lena seamounts (Borisova et al., 1996) showed that these lavas were formed by melting of the ancient subcontinental mantle underlying the Conrad Plateau. Apart from basalt samples, rocks of the continental type were collected from the surface of these mountains (Ishchenko and Katsuk, 1992). In addition, the Japanese R/V Hakuho Maru recently raised more than $60 \mathrm{~kg}$ of metamorphic and granite rocks from the surface of the $\mathrm{Ob}$ ', Lena, and adjacent smaller seamounts.

Gravimetric studies were carried out on the Ob', Lena, and Marion Dufresne horst blocks during voyages of R/V Marion Dufresne MD-5 (1975) and MD-11 (1976). 2D modeling of gravimetric data (free-air anomaly) along the profiles intersecting these structures showed crust thickening up to $35 \mathrm{~km}$ with background values within $10-15 \mathrm{~km}$, the estimated average crust density being $3 \mathrm{~g} / \mathrm{cm}^{3}$ (Goslin, 1979). If the den- sity was $2.8-2.9 \mathrm{~g} / \mathrm{cm}^{3}$, as is usually assumed for the crystalline crust, then the thickness of the Earth's crust of the Konrad Plateau would certainly exceed the values that were obtained.

Both the Del Cano-Crozet and Conrad plateaus are examples of so-called aseismic ridges and are characterized by the absence of linear magnetic anomalies characteristic of riftogenic mid-ocean ridges. Considering this circumstance, Le Pichon called Crozet Plateau a dead ridge, thus emphasizing its sharp contrast in relation to the riftogenic West Indian Ridge (Le Pichon, 1968). It is also believed to be a continental formation by origin (Laughton et al., 1970). The common genesis of both plateaus is also evidenced by the features of the structural-tectonic map of the southern sector of the Indian Ocean. Thus, as can be seen from the submeridional profile crossing this region (see Fig. 3b), the Del Cano-Crozet and Conrad plateaus, as well as smaller blocks, are located on a vast four-way dip uplift of the basement relative to the basins with depths of more than $5.5 \mathrm{~km}$, which, despite the bottom surface leveling by the sedimentary cover, is clearly expressed in the relief. The basement ledge forms a structural barrier that prevents sediments from moving away from the Antarctic continent, as a result of which the thickness of the sedimentary cover in the pericontinental Antarctic Trough is $4-5 \mathrm{~km}$, whereas its thickness in the Crozet Basin is estimated at several hundred meters. In terms of morphological features, structural features of the sedimentary cover, and crust thickness, both plateaus resemble the flat-topped Madagascar Ridge (plateau), which is a structural continuation of Madagascar Island. The ridge has a minimum depth of $20 \mathrm{~m}$ observed in the area of Walters Shoal (see Fig. 2).

Taking into account all of the above, we can conclude that both plateaus and the Madagascar Ridge are fragments of a relict platform structure with a preserved crust of continental type, which was dissected by a riftogenic ridge. The continental crust was significantly reworked by destructive tectonomagmatic processes in the rifting zone and adjacent areas.

Kerguelen Plateau. One characteristic morphological feature of this plateau is the three volcanic islands crowning it (Fig. 4) and an archipelago numbering about 400 small islands and rocks (Watkins et al., 1974; Recg and Charvis, 1986). Kerguelen Island and Archipelago are located in the northern part of the plateau, while Heard and McDonald Islands are $450 \mathrm{~km}$ southeast of it. Kerguelen, the largest island, was discovered in 1772 by French navigator YvesJoseph de Kerguelen, after whom the island and plateau were named.

The Kerguelen Plateau is the largest structure of the bottom of the Indian Ocean, comparable in size to Madagascar Island. Published estimates of the plateau length vary from 2000 to $2500 \mathrm{~km}$. In fact, the distance between its northwestern tip at a depth of $4.0 \mathrm{~km}$ and 
(a)

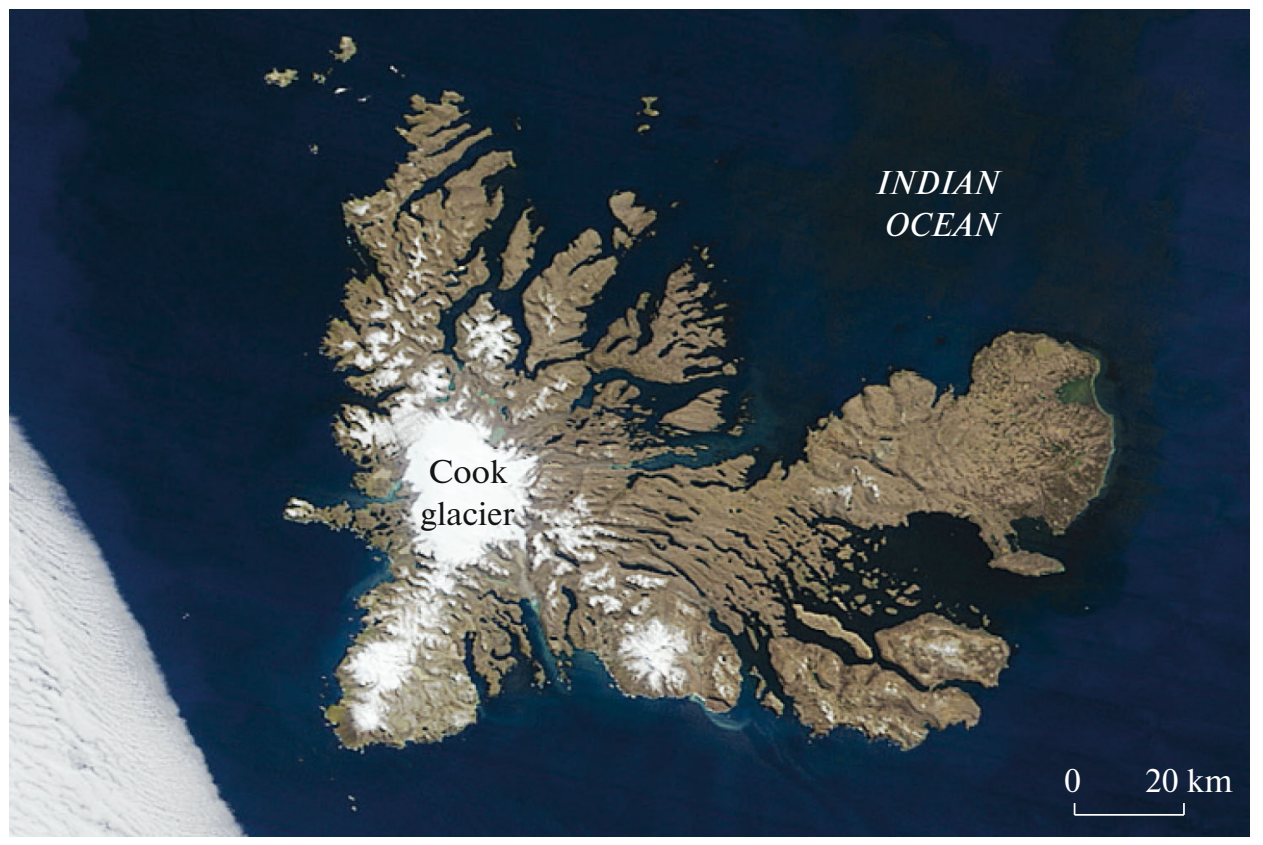

(b)

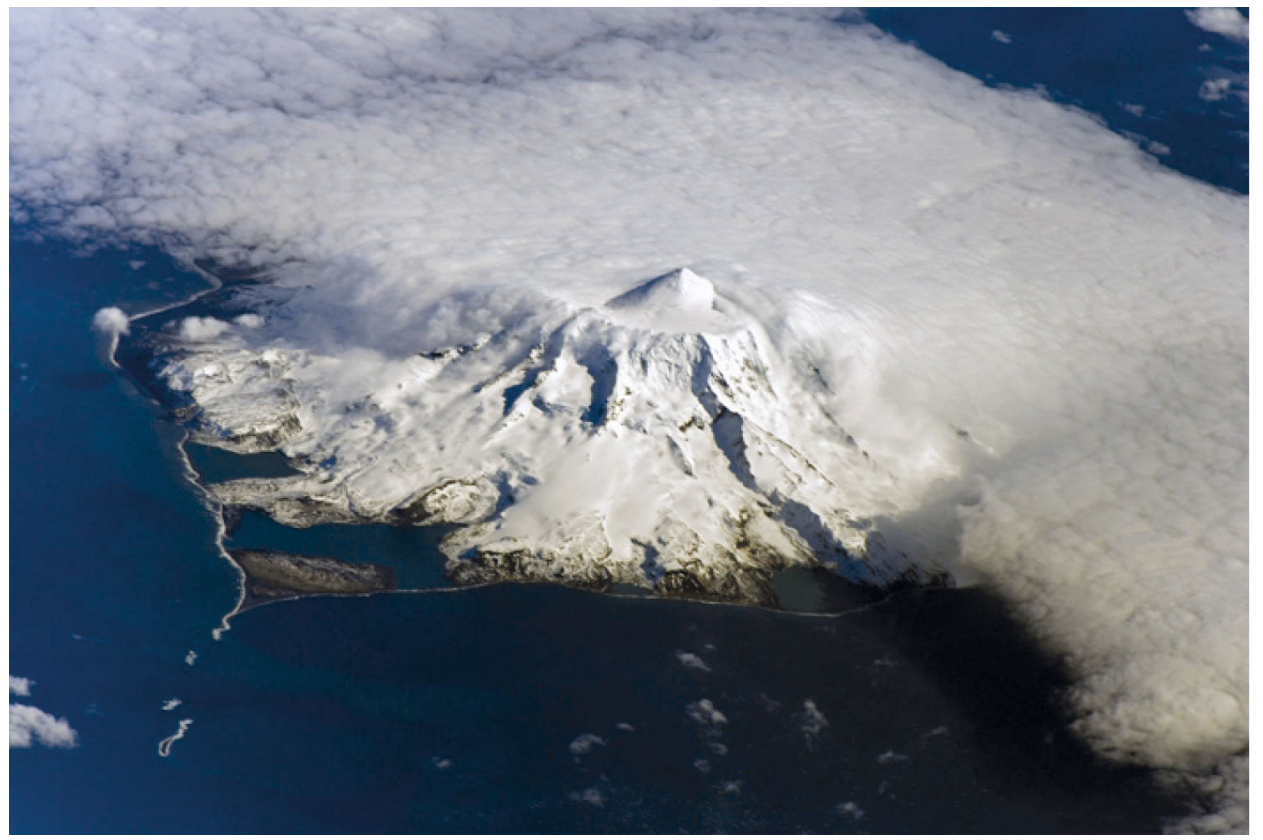

Fig. 4. Volcanoes of the Kerguelen Plateau. (a) Kerguelen volcano (the picture was taken from a NASA satellite) and (b) Heard volcano (picture taken from the ISS).

the southeastern tip at a depth of 3.5 is $2300 \mathrm{~km}$, which, with acceptable accuracy, corresponds to the length of the plateau in the north-northwest direction. The average width of the Kerguelen Plateau is 400$500 \mathrm{~km}$; in the southern part it increases to $700 \mathrm{~km}$.

If we consider the Kerguelen Plateau and the Gaussberg volcano components of the KerguelenGaussberg Ridge (Watkins et al., 1974, etc.), then the length of this structure increases by $250 \mathrm{~km}$. The Gaussberg volcano $\left(66^{\circ} 48^{\prime} \mathrm{S}, 84^{\circ} 11^{\prime} \mathrm{E}\right.$; altitude $\left.370 \mathrm{~m}\right)$ is located in the Davis Sea coastal sector on Kaiser Wilhelm II Land (see Fig. 2).

The Kerguelen Plateau has two large ledges, the Skiff Bank (also called the Leclaire Ridge), with a minimum depth of $130 \mathrm{~m}$, and the Elan Bank, located at a depth of $910 \mathrm{~m}$. Accumulative plain Valdivia, with depths of 4.5-4.6 km, lies between them. The seismoacoustic section (Fig. 3c) shows that the plain lies on the lowered western wing of the Kerguelen Plateau, the subsidence of which is compensated by sedimenta- 
tion. A partially buried large horst outlier Mount Kohler with a minimum elevation of $2100 \mathrm{~m}$ rises in the central part of the plain. The northwestern part of the Valdivia Plain is crossed by the Kerguelen Fault, expressed in relief in the form of two parallel stretching trenches separated by a horst ledge of the basement. It is notable that there are no cover sediments in the trenches, which suggests that they are young superimposed tectonic structures (see Fig. 3a).

Ramsay et al. (1986) identified the northern and southern morphological provinces, as well as the Williams Ridge, partially isolated from the plateau by the Labuan Basin within the Kerguelen Plateau. Some researchers additionally identify the central part of the plateau and the Elan Bank as separate provinces (see, e.g., Borissova et al., 2003). However, given the erosion-accumulative processes widely developed on the Elan Bank, it should be considered an integral part of the genetically homogeneous leveled surface, which is the main morphological feature of the Kerguelen Plateau.

The northern and southern parts of the plateau are separated by the Fawn Trough with a depth of $2.8 \mathrm{~km}$ (Roquet et al., 2009). Judging by the abrasive shearing of the sedimentary cover layers exposed on its sides, this is the bed of the relict channel, which is divided into two deep canyons in the western part of the plateau that pass by the Elan Bank from the northern and southern sides (see Figs. 3a, 8).

The northern part of the plateau with the Kerguelen, Heard, and McDonald islands lies within the depth range of $1.0-1.2 \mathrm{~km}$. It is characterized by a leveled top surface, formed by abrasion-accumulative processes. Detailed bathymetric studies carried out by Australian researchers revealed a number of banks in addition to the Skiff and Elan banks south of Kerguelen Island, i.e., Pike, Discovery, Vicinity, Coral, Aurora, and Shell (Beaman et al., 2011; Duncan et al., 2016).

The southern part of the plateau, which, in contrast to the northern one, has a more contrasting relief, is located mainly within the depth range of $1.5-2.5 \mathrm{~km}$; the minimum depth, confined to the Banzare Bank, is $165 \mathrm{~m}$ below sea level. A number of characteristic horst structures stand out here, which, in addition to the aforementioned Banzare Bank, include Bank Corinth, the Umitaka-Maru Ridge, and others. The denuded surfaces of these formations, which had been forming under aerial conditions for a long time (tens of millions of years), acquired a characteristic domelike shape. Dredging on the Banzare Bank showed that it is composed of highly altered weathered basalts, granites, and metamorphic rocks (Ramsay et al., 1986). Another feature of the southern part of the plateau is the Raggatt sedimentary basin, located east of the Banzare Bank. The thickness of the sedimentary layer in the basin reaches $4 \mathrm{~km}$ (Ramsay et al., 1986).

Between the southern tip of the Kerguelen Plateau and the Antarctic Princess Elizabeth Coast, there is a saddlelike structure of the bottom relief with the width of $170 \mathrm{~km}$ along the $3 \mathrm{~km}$ isobath and a leveled bottom at a depth of $3.6 \mathrm{~km}$, which structurally separates the sedimentary basins of the two largest depressions, the Australian-Antarctic and the African-Antarctic. Initially, this area was called the Challenger Passage "to denote a narrower and shallower part of the rampart connecting these two structural protrusions" (Vanney, Johnson, 1982) (see Fig. 3d). At present, the area between the Kerguelen Plateau and East Antarctica is called either the Princess Elizabeth Trough (Wallace et al., 2002; Borissova et al., 2003; Davis et al., 2018; etc.) or the Princess Elizabeth Basin (Leichenkov et al., 2015).

The question of whether or not there is a structural connection between the plateau and the mainland is of fundamental importance. Recognizing the existence of such a connection means that the Kerguelen Plateau should be considered a large structural inlier, like the Antarctic Peninsula, located in the western part of Antarctica, which would require a radical revision of the existing plate tectonic constructions.

The main morphostructural feature of the Kerguelen Plateau is distinctive tectonic elements typical of horst structures. The location of banks at different depths indicates active tectonic movements of different intensity having taken place on the plateau, which led to the formation of horst and graben structures. The flexure, developed on the southwestern slope, was formed as a result of extensive areal subsidence of the western periphery of the plateau. The opposite, northeastern slope, including the William's Ridge, which Houtz called the "structural ledge" (Houtz et al., 1977), is dominated by large-amplitude fault ledges, with displacement of all layers of the sedimentary cover and basement. Such tectonic "slices" should be considered structural signs of the latest phase of tectonic activation, manifested in the late MiocenePleistocene, which ultimately formed the modern appearance of the plateau.

Kerguelen archipelago. Volcanic Kerguelen Island, which rises up to $1850 \mathrm{~m}$ above sea level, is formed by the overlap of four main shield volcanoes, overlain by two large, younger alkaline stratovolcanoes $6 \mathrm{Ma}$ old, overlain by a layer of pyroclastic rocks of 2 to $0.5 \mathrm{Ma}$ in age (Nouger, 1969; Dosso et al., 1979). The volcanoes are complicated by parasitic cinder cones fed along cracks branching from the main vent, basanite and trachyte domes, phonolite plugs, and rhyolite flows.

The question of the nature of the archipelago was raised at the beginning of the 20th century and was formulated as follows: whether the islands, including Heard Island, are volcanoes that developed on an ancient continental basement or if they formed on an oceanic plateau as a result of the outpouring of Cenozoic basaltic lavas. This question arose when the outcrops of weathered mica diorite and ancient dolomites 
were discovered on Kerguelen Island (Filippi 1908) and granites and gneisses were found on Heard Island (Pronin, 1977).

One of the main geological features of Kerguelen Island is a granite-syenite pluton located on the Rallier du Baty Peninsula in the southwestern part of Kerguelen Island (Nougier and Lameyre, 1972). In addition to the main pluton, 15 more plutonic complexes have been described on the archipelago (Giret, 1990). The problem of their origin is reduced to solving the question of whether the plutons are the result of differentiation of the oceanic type of crust or they if reflect the presence of a sialic basement.

From the standpoint of plate tectonics, the Kerguelen volcano is a so-called hot spot that appeared in the Early Cretaceous (115-135 Ma BP) and has retained magmatic activity until the present. It is believed that the products of magmatism of this hot spot created the Kerguelen Plateau, the West Australian Ridge, and the East Indian Ridge (Frey et al., 2000). However, as has been shown by a comprehensive analysis of geological, geochemical, and geophysical data, the West Australian and East Indian ridges were laid on the continental crust. Their features indicate a long and complex tectonic evolution which cannot be explained solely by the activity of the hot spot (Illarionov et al., 2019, 2020).

A similar situation with the "hot spot-tracer ridge-transform faults" succession was considered for the northeastern part of the Indian Ocean, where volcanic edifices are widespread and there is a dense network of parallel sublatitudinal faults. These faults are formed by a system of narrow troughs associated with the dikes of intrusive bodies (diapirs), which break through the basement and sedimentary cover. Tectonically, the faults form a superimposed structure corresponding to the latest stage of tectonic activation, and by their nature they are not transform faults (Illarionov and Boyko, 2018). The study of the volcanic islands showed that their ages are from 47 to $136 \mathrm{Ma}$; they are scattered rather chaotically and not associated with the East Indian Ridge or submeridional faults by age trends. The age of volcanoes depends to a large extent on their location. Thus, the youngest volcanoes were found on the Cocos Islands and the oldest were found in the Argo Basin. Most of the flat-topped mountains (guyots) were islands. At present, these islands are submerged to $1.2-3.0 \mathrm{~km}$ below sea level, which indicates the amplitude of vertical movements in the region. Geochemical analysis has shown that recycled continental crust is involved in the structure of volcanoes (Hoernle et al., 2011). Thus, the study of volcanoes in the northeastern sector of the Indian Ocean did not confirm the hot spot-tracer ridge-transform faults plate tectonic model.
Critical Review of Deep Seismic Sounding Data. Analysis and Geological Interpretation of the Results

A study of the Earth's crust by deep seismic sounding (DSS) on the Kerguelen Plateau was carried out in the following areas: in the northern part of the plateau, directly on the Kerguelen archipelago; in the central part of the plateau, between the archipelago and the Heard and McDonald islands; in the southern part of the plateau, in the area of the Raggatt sedimentary basin; on the bank Elan; and in the Enderby Basin and Prydz Bay (East Antarctica) (Fig. 5).

Structure of the Earth's crust in the northern part of the plateau in the area of the Kerguelen Arcipelago. (see Fig. 5, test site I) DSS studies in this area were carried out by French researchers in 1987 (Recq et al., 1990). Seismic stations were placed along two orthogonal intersecting profiles; they recorded signals from land and sea explosions. The velocity section was interpreted as a crust section of the oceanic type. The upper layer, $8-10 \mathrm{~km}$ thick, with an average seismic velocity of $5.5 \mathrm{~km} / \mathrm{s}$ (which was believed to be the second oceanic layer) and the lower (third oceanic layer), with a thickness of 4-10 km and an average velocity of $6.6 \mathrm{~km} / \mathrm{s}$, were distinguished. At the base of the section, a transitional layer of increased velocity $(7.2-7.4 \mathrm{~km} / \mathrm{s})$ with a thickness of $2 \mathrm{~km}$ was detected. The next boundary below, with an underlying velocity of $7.8 \mathrm{~km} / \mathrm{s}$, was interpreted as the top of the low-velocity mantle. The Moho discontinuity was determined on a sub-latitudinal profile that crossed the southern edge of the island, while no refractive seismic waves from the Moho discontinuity were recorded on a profile passing through the entire island submeridionally. It can be assumed, therefore, that the Earth's crust under the island is much thicker than $22 \mathrm{~km}$. This crust thickness was determined on the southern tip of the island.

From the materials presented in the article (Recq et al., 1990), it can be seen that two orthogonal velocity sections are not the same at the points of profile intersections; that is, the sections along the intersection line have different velocity characteristics in the same place, depending on the direction of study. Considering that the Earth's crust in the northern part of the plateau has a complex three-dimensional structure, in order to get the most reliable idea of its structure and the nature of its constituent layers, one should carry out a three-dimensional modeling of the gravitational field based on the seismic deep sections.

When interpreting the high-speed section, it should be born in mind that xenoliths of basic granulites were discovered on the Jeanne d'Arc Peninsula in the southeastern part of the Kerguelen Island (Gregoire et al., 1994). Granulites were found only in continental regions where the crust is thick enough to withstand the high temperatures and pressures required for the crystallization of granulite facies minerals. It should also be added that the presence of continental crust in the northern part of the Kerguelen Plateau is also indi- 


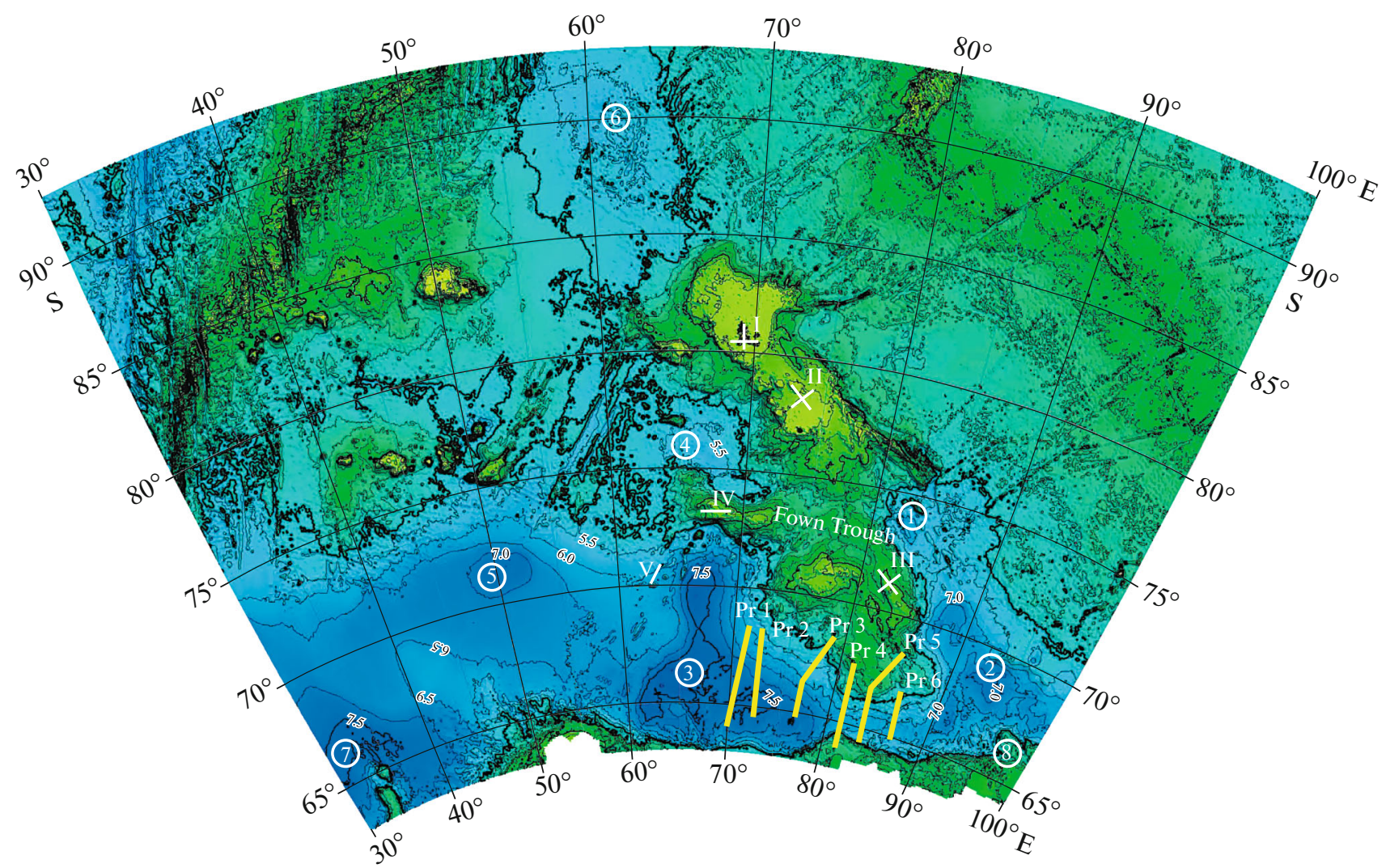

Fig. 5. Map of the acoustic basement in the study area (Lambert projection). Numbers in circles: (1) Labuan Basin, (2) Shackleton Basin, (3) Enderby Basin, (4) Valdivia Plain, (5) Conrad Basin, (6) Crozet Basin, (7) Gunnerus Basin, and (8) Bruce Plateau. (Pr 1-Pr 6) Profiles: (Pr 1) RAE 52-2, (Pr 2) RAE 52-06, (Pr 3) RAE 52-09, (Pr 4) RAE 39-10, (Pr 5) RAE 48-08, and (Pr 6) GA 228-10 (sections along the profiles are shown in Fig. 6). (7.0) Isoline depth, km. Roman numerals are DSS test sites: (I) in the area of Kerguelen archipelago, (II) in the central part of the plateau, (III) in the southern part of the plateau, (IV) on Elan bank, and (V) in the Enderby basin.

cated by the fact that granites and syenites were dredged from the southern slope of the Skiff Bank during cruise MD109-Kerimis in 1998 (dredge 1, $\left.50^{\circ} 21^{\prime} \mathrm{S} ; 63^{\circ} 48^{\prime} \mathrm{E}\right)$. However, since these are "very unusual rocks for the oceanic environment," they were interpreted as ice-rafted material (Weis and Frey, 2002).

Taking into account the above facts, another interpretation of the geophysical data can be proposed. A seismic velocity increase from 4.6 to $6.6 \mathrm{~km} / \mathrm{s}$ is observed in the $20-22 \mathrm{~km}$ thick section. This pattern, firstly, is due to the natural increase in the velocity and rock density with depth. Secondly, such a section is a distinctive of the crust of continental type, the upper part of which corresponds to the granite-gneiss layer, while the lower layer (with increased velocities of 6.8$7.2 \mathrm{~km} / \mathrm{s}$ ) corresponds to the granulite-basite layer (Pavlenkova, 2002). The layer of increased velocities at the base of the crust is characteristic of relict continental uplifts in the ocean (Frolova, 2001). It was established on the Agulians Plateau and the Seychelles, formed by the continental crust (Udintsev, 1987). Thus, the section under consideration indicates rather a subcontinental type of the Earth's crust in the north- ern part of the Kerguelen Plateau, which is possibly thicker, since there is no confidence in the reliability of the reflections from the Moho discontinuity

Deep seismic surveys in the central part of the Kerguelen Plateau. (see Fig. 5, test site II) Research between Kerguelen archipelago and Heard Island was carried out along two orthogonally intersecting profiles. An array of five bottom seismic stations with an interval of $20 \mathrm{~km}$ was used (Charvis and Operto, 1999). The experiment schedule included also work along the profile in the Enderby Basin in order to reveal differences in the structure of the Earth's crust under these heterogeneous structures. The sections at the test site turned out to be quite substantiated, since the seismic section was close to one-dimensional, which made it possible to regard the structure of the Earth's crust as a layered, horizontally homogeneous structure and apply the Fuchs-Muller reflectivity method for onedimensional media to calculate synthetic seismograms (Fuchs and Muller, 1971). The simulation results were in a good agreement with the dynamic picture of the wave field. 
Crust thickness in the survey area was assessed as $25 \mathrm{~km}$ and "normal" velocity at the Moho discontinuity was $8 \mathrm{~km} / \mathrm{s}$. Three velocity layers were distinguished in the structure of the crystalline crust with a total thickness of $19-21 \mathrm{~km}$. The upper $1.2-2.3 \mathrm{~km}$ thick sedimentary layer is characterized by a velocity range from 3.8 to $4.9 \mathrm{~km} / \mathrm{s}$. The thickness of the middle layer is $2.3-3.3 \mathrm{~km}$, and the range of velocities is from 4.7 to $6.7 \mathrm{~km} / \mathrm{s}$. The lower layer with a thickness of about $17 \mathrm{~km}$ is characterized by velocity of $6.6 \mathrm{~km} / \mathrm{s}$. At the base of the crust, there is a high-velocity layer $(6.8-7.4 \mathrm{~km} / \mathrm{s})$, which, as noted above, is a characteristic of continental uplifts in the ocean. In our opinion, which is shared by many other researchers studying the structure of the ocean floor, this section indicates a subcontinental type of the Earth's crust in the central part of the Kerguelen Plateau (Borissova et al., 2003; etc.).

Seismic exploration of the southern part of the Kerguelen Plateau. (see Fig. 5, test site III) In this region, bottom seismographs were also placed along two intersecting profiles with five stations at each with an interval of $25 \mathrm{~km}$ (Operto and Charvis, 1995). The results revealed well-grounded sections close to the one-dimensional environment model. The crust thickness and depth of the Moho discontinuity (24$26 \mathrm{~km}$ ) were very close to the values obtained on the Kerguelen Island and on the test site located to the north. However, this section is distinguished by a higher mantle velocity, $8.6 \mathrm{~km} / \mathrm{s}$. The mantle waves were traced up to a distance of $140 \mathrm{~km}$ and the value of its velocity is beyond doubt.

Two layers were distinguished in the structure of the crystalline crust. The upper layer is approximately $5.0 \mathrm{~km}$ in thickness with velocities ranging from 3.8 to $6.5 \mathrm{~km} / \mathrm{s}$, while the lower one is $\sim 11-\mathrm{km}$-thick with velocities of $6.6-6.9 \mathrm{~km} / \mathrm{s}$. In the lower part of the section at the Moho discontinuity, there was a relatively low-velocity layer, defined as a transitional zone of "reflectivity," with a thickness of 4-6 km and velocities of $6.7-6.9 \mathrm{~km} / \mathrm{s}$. The presence of this layer suggested that the southern part of the plateau is composed of thinned continental crust (Frey et al., 2000). The authors of the paper (Operto and Charvis, 1995) believed that the structure of the southern part of the plateau has common features with the section of the Rockall Bank in the Northwest Atlantic, where, according to their opinion, stretched (or, in our opinion, thinned, as a result of processing of its lower layers) continental crust is overlain by a thick basalt stratum.

Seismic surveys at Elan Bank. (see Fig. 5, test site IV) The sub-latitudinal profile on the bank consisted of five bottom seismic receivers every $20 \mathrm{~km}$. The crust thickness on the bank is at least $15 \mathrm{~km}$ (Kónnecke et al., 1997). The upper $2-3 \mathrm{~km}$ thick layer of igneous rocks has velocities from 4.4 to $5.9 \mathrm{~km} / \mathrm{s}$. It is interpreted as a lava flow originating from the Kerguelen hotspot, $500 \mathrm{~km}$ away from the bank (Borissova et al.,
2003). A 14-km-thick layer of continental crust lying at the bottom has typical velocities of $6.0-6.6 \mathrm{~km} / \mathrm{s}$.

The array spans do not allow reliable refractions at the Moho discontinuity to be obtained; therefore, the hypothetical mantle velocity of $8.6 \mathrm{~km} / \mathrm{s}$ seems very questionable. The seismic records of bottom sensors 1 and 5, located at the ends of the profile, show signs of a layer of reduced velocity in the lower crust. Taking into account this layer, the section resembles those obtained on the southern flank of the Kerguelen Plateau and in the Princess Elizabeth Trough. To obtain more precise results, the DSS section must be processed together with the CMP data obtained in the same area.

Before deep-sea drilling was carried out on the bank, it was believed that it was composed of oceanic crust. However, the results of drilling well ODP-1137 has provided undeniable geological evidence for the presence of a continental crust in its structure. Taking into account these geological data, the seismic section received an appropriate interpretation.

DSS Survey in the Enderby Basin. (see Fig. 5, test site V) According to the results, the sediment thickness in the section varies from 30 to $300 \mathrm{~m}$. The authors of (Charvis and Operto, 1999) explain the insignificant thickness of this layer, which lies on the Cretaceous oceanic crust, by erosion by strong currents from the Kerguelen Plateau. The velocity in layer 2 varies from 4.4 to $5.1 \mathrm{~km} / \mathrm{s}$ in the upper part to 6.3 to $6.5 \mathrm{~km} / \mathrm{s}$ in the lower part. In the upper part of layer 3 , the velocity varies from 6.7 to $6.87 \mathrm{~km} / \mathrm{s}$ at depths between 6.0 and $9.3 \mathrm{~km}$ and reaches values of $7.24-7.32 \mathrm{~km} / \mathrm{s}$ at the base of the layer. The Moho discontinuity plunges towards the plateau from 15 to $18 \mathrm{~km}$ and is associated with thickening of the magmatic crust from 10 to $15.2 \mathrm{~km}$. Velocity at the Moho discontinuity is $8.1 \mathrm{~km} / \mathrm{s}$. Charvis and Operto (1999) believe that the large $(10-13 \mathrm{~km})$ thickness of the sediments with a velocity of $7.4 \mathrm{~km} / \mathrm{s}$ is characteristic of the oceanic crust near the hot spot. In fact, it can be seen on the maps (see Figs. 3, 5) that the profile is located on the part of the Elan Bank basement submerged towards the Enderby Basin, and its structure is in good agreement with the section of this bank. At the same time, there is a regularity in the decrease in the thickness of the layers and the rise of the Moho discontinuity from $18 \mathrm{~km}$ under the Elan Bank to $15 \mathrm{~km}$ on the northeastern slope of the Enderby Basin. Therefore, the crust of the Enderby Basin, at least in the area of the profile, as well as the crust of the Elan Bank, is continental, but somewhat thinner than the latter.

Seismic Surveys in the Princess Elizabeth Trough and the Enderby Basin. (see Fig. 3, Pr 6, 7) Two seismic profiles, RAE52-11 along the meridian $73^{\circ} \mathrm{E}$ and RAE-4808 along the meridian $84^{\circ} \mathrm{E}$, were acquired in the area of the Princess Elizabeth Trough during Russian Arctic expeditions (RAE) (in Fig. 5, the profiles are designated as $\operatorname{Pr} 1$ and $\operatorname{Pr} 5$, respectively). Within 
the framework of the joint Russian-German project of the International Polar Year in 2007-2008 in the same region, two sections were acquired by the DSS method with bottom stations of the Alfred Wegener Institute (AVI) of the Helmholtz Center for Polar and Marine Research, Germany. The AWI-20070200 and AWI-20070100 profiles were combined with the RAE4808 and RAE52-11 profiles, respectively (Gohl et al., 2007; Leichenkov et al., 2015). Thus, we we obtained excellent experimental results characterizing the structure of two different morphostructures, the Enderby Basin and the saddle structure connecting the Kerguelen Plateau and Antarctica.

However, judging by the published works, interpreting the section through the saddle (or the Princess Elizabeth Trough, as indicated in the article) was ambiguous. In the works (Gohl et al., 2007; Leichenkov et al., 2010), a layer of reduced velocity was identified in the lower crust of the section, while a later publication (Leichenkov et al., 2015) presented a velocity model without such layer. This model was obtained using a ray path calculation of wave fields in the geometrical optics approximation of one bottom station without any binding theoretical times to the data or data-based hodographs. Unfortunately, the velocity data processing did not comply with the existing standards presented, e.g., in the publications of French colleagues. The main topic of a later publication (Leichenkov et al., 2019) was again the velocity section through the saddle obtained in 2007. However, instead of providing a valid model of the deep seismic section, the authors of the article combined the upper part of the section constructed from the CMP data and the lower part of the section, built earlier according to the data of the abovementioned DSS experiment, and used it for density modeling of the gravity anomaly. Based on these calculations, the authors reconstructed the history of the thermal evolution of the Princess Elizabeth Trough. However, without a reliable velocity section that would give the initial baseline parameters (the section was never obtained), these gravimetric and thermometric calculations seem unconvincing.

The combined profile of the CMP reflection method (RAE52-11) and DSS (AWI-20070100) in the Enderby Basin (in Fig. 5 designated as Pr 1) was continued by the work performed by the Polar Marine Geological Research Expedition (PMGRE) in a southern direction further turning to the south-southeast towards the Prydz Bay (see Fig. 1), where in 1981 the seismic DSS-CMP profile was passed across the strike of the bay (Masolov et al., 1981). This profile was surveyed using the CMP reflection method and the point placement of sensors to determine the velocity characteristics of the section. Thus, a seismic survey was carried out along the regional profile that extends from the southern part of the Kerguelen Plateau to the eastern edge of Antarctica, crossing the mouth of the Prydz Bay.
Density modeling was carried out along the profile PMGRE 5206 (Leichenkov et al., 2015) with a length of about $800 \mathrm{~km}$. The upper part of the profile clearly shows the structure of the sedimentary cover in the Lambert Rift, refining the results of the work in 1981. However, the depth of the Moho discontinuity shifted downward by $4 \mathrm{~km}$, from 20 to $24 \mathrm{~km}$, in comparison with the data of the DSS in 1981, which is unacceptable. Seismic data are more reliable in determining depth of the Moho discontinuity, and it is always possible to find a density model that satisfies both seismic and gravity data while maintaining the discontinuity position obtained from the seismic data. However, even in a later publication on the interpretation of the 1981 data, the authors left the depth of the Moho discontinuity at the same depth (Kanao et al., 2014). Otherwise, they would have to revise the processing and interpretation of DSS seismic data. This property is satisfied by the density model of the Lambert Rift (though more coarse and without details of the structure of the upper part of the section), obtained back in 1983 (Kadmina et al., 1983). This model has a pretty obvious explanation. With an even Bouguer anomaly over the rift, the position of the Moho discontinuity $(20 \mathrm{~km})$ compensates for the lens of low-density $\left(2.4 \mathrm{~g} / \mathrm{cm}^{3}\right)$ rocks in the rift.

One important conclusion could be inferred from a brief analytical review of seismic materials and their geological interpretation. Seismic sections obtained along the strike of the Kerguelen Plateau are characterized by relative homogeneity and simplicity of structure, which indicates a weak horizontal heterogeneity of the plateau crust. Such a crust section indicates the genetic uniformity of the plateau structure, rather than a heterogeneous mosaic-block structure. The presence of a thick (at least $15-\mathrm{km}$ ) layer of the continental crust certainly indicates the continental nature of the Kerguelen Plateau.

\section{Geochemical Analysis}

The geochemical analysis of the basalts uncovered by drilling on the Kerguelen Plateau has shown that they are contaminated with the material of the continental crust. However, as was mentioned already, these results have not received an unambiguous assessment; they can be interpreted both in favor of the continental nature of the basement and the oceanic nature of the plateau, with the mantle source heavily contaminated with continental material.

One important petrogenetic issue in relation to the magmatism of the Kerguelen Plateau is the relative contribution of the continental crust to plume magmatism (Weis et al., 1986; Dosso et al., 1988; Davies et al., 1989; Schlich and Wise, 1989; Salters et al., 1992; Storey et al., 1992; Mahoney et al., 1995; Frey et al., 2000, 2002; Borisova et al., 2002, 2014, 2017; Weis and Frey, 2002; Bénard et al., 2010). The database, expanded due to new results, contains more than 100 geological sam- 
ples of basalt and sedimentary rocks. In addition, we studied samples of silicic rocks collected during the voyages of R/V Marion Dufresne (MD 48 and MD 109).

Well ODP-747, drilled in the central part of the plateau, and wells 749 and 750 in the southern part, exposed effusive rocks composed of moderately fresh to highly altered tholeiitic basalts and andesitebasalts. Lavas from wells 749 and 750 are moderately enriched in light rare-earth elements (REE) $\left((\mathrm{La} / \mathrm{Sm})_{n}=1.0-1.3\right.$ and $\left.0.8-1.2\right)$ and $(\mathrm{La} / \mathrm{Nb})_{n}=$ (0.9-1.3 and $0.9-1.1$, respectively) and resemble basalts of the Southeast Indian Ridge (Dosso et al., 1988). Unlike basalts from well 738 ODP, located in the southernmost part of the Kerguelen Plateau (Mahoney et al., 1995), basalts from wells 749 and 750 have no obvious geochemical signs of continental crust contamination. Basalts from well 747 are the most enriched in light $\operatorname{REE}(\mathrm{La} / \mathrm{Sm})_{n}=1.8-2.5$ among basement tholeiites and are depleted in $\mathrm{Nb}$ and Ta with $(\mathrm{La} / \mathrm{Ta})_{n}$ and $(\mathrm{La} / \mathrm{Nb})_{n}$ up to 2 . They have moderate $(\mathrm{Th} / \mathrm{Ta})_{n}=0.8-1.5$, and variable Th depletion is expressed in high $(\mathrm{La} / \mathrm{Th})_{n}=1.2-1.9$. In this respect, they differ from the basalts from well 738 and samples dredged during cruise MD 48. We assume that the basalts from wells 738 and 747 were heavily contaminated with various components of the continental crust.

The basalts from wells $738,747,749,750$, and MD 48 have different $\mathrm{Sr}$ and $\mathrm{Nd}$ isotopic compositions ranging from basalts of the Indian Ocean (borehole 749) to the assumed composition of the Kerguelen plume (Weis and Frey, 2002), as well as to values which clearly reflect continental crust contamination (wells 738 and 747). Nonradiogenic $\mathrm{Nd}$ and a wide range of $\mathrm{Pb}$ isotopic composition, $\mathrm{Nb}-\mathrm{Ta}$ depletion and variable Th content in the basalts from wells 747 , 738 , and MD 48 suggest the participation of continental crust with a $\mathrm{Sm} / \mathrm{Nd}$ ratio that is low-integrated over time, relative depletions of $\mathrm{Nb}$ and $\mathrm{Ta}$, and variable $\mathrm{U} / \mathrm{Pb}$ and $\mathrm{Th} / \mathrm{U}$ ratios. It is noteworthy that the tholeiites of wells 747, 738, and MD 48 contaminated by continental crust are located in different parts of the Kerguelen Plateau.

A wide range of silica-rich metamorphic and igneous rocks have been recovered from many locations in the northern (MD 109, dredge 1), central (MD 48, dredges 1,7 , and 8), and southern (MD 48, dredges 3 and 6) parts of the plateau. They had previously been interpreted as detrital material brought by ice rafting (Davies et al., 1989). The results of the ODP-183 cruise, however, when siliceous lavas, garnet-biotite gneiss, and granite were found in the cores of the wells (Frey et al., 2000), have shown that this interpretation should be revised. These data confirmed the participation of continental crust in the formation of the Kerguelen Plateau (Frey et al., 2002). Geochemical contamination with continental material has been proven for all studied igneous rocks of the southern and central parts of the Kerguelen Plateau except for the basalts of the northern zone, which mostly bear signs of oceanic magmatism. The structure of the southern part of the Kerguelen Plateau, as well as the Elan Bank, contains a continental crust (Bénard et al., 2010).

Borisova et al. $(2002,2014,2017)$ carried out a detailed study of samples of the most primitive basaltic lava ever found on the islands and the Kerguelen Plateau, which erupted 21-19 Ma ago: picrite basalts (MD109-D6-87), collected during a cruise of R/V Marion Dufresne on the seamount between the Kerguelen archipelago and Heard Island. This study shows significant heterogeneity of the initial melts $(\mathrm{MgO}=7-10 \mathrm{wt} \%)$ crystallized at early stages at high pressure (200-300 MPa) and relative homogeneity of those crystallized at a later stage at lower pressure $(100 \mathrm{MPa})$. These data are interpreted in terms of mixing of the plume and assimilated melts in the magma chamber before being transported to the surface. Magma Chamber Simulator (MCS) thermodynamic modeling was used to interpret the data. These results underscore the importance of the influence that the assimilation of the gabbroid crust can have on the geochemistry of mantle olivine-porphyry magmas. The possibility of crust assimilation and the resulting change in the composition of primitive plume basaltic magmas suggests that the isotopic and chemical equilibrium between the basalts of oceanic islands and associated sources in the deep plume mantle is the exception rather than the rule. That is, the isotopic anomalies of the Kerguelen Plateau are apparently associated with the crust, and not with the mantle contamination of basaltic melts.

A recent study of syenite rocks of the intrusive complex on the Ralier du Bati peninsula of the Kerguelen Island (SRBIC) indicates that this laccolith was formed between 11.6 and 7.9 Ma ago due to successive intrusions of magmatic melts with an average velocity from 0.8 to $1.4 \times 10^{-4} \mathrm{~km}^{3} /$ year. These results reveal the complete similarity between SRBIC, the only recorded case of acidic laccolith in an oceanic intraplate setting, and many continental plutons located in different geodynamic settings. Thus, SRBIC has the characteristics of a continental plutonic complex located in the oceanic zone (Ponthus et al., 2020). The proposed ideas about how plutonic processes worked on the Kerguelen Plateau are important in the context of the general interpretation of alkaline magmatism, especially in light of the comparison of the thickened oceanic Kerguelen lithosphere and the thinned continental lithosphere made by Grégoire et al. (1998), based on the examination of the main granulite xenoliths of the islands of the Kerguelen archipelago. The results indicate that the geochemical and petrological anomalies of the plateau and islands are associated with the crust, and not with the mantle contamination of basaltic melts, as well as with the continental nature of the Kerguelen Plateau. 


\section{Geological Structure and Tectonics of the Kerguelen Plateau and Adjacent Areas}

On magmatism on the Kerguelen Plateau. The issues discussed in the previous sections call for clarifying the role of magmatism in the geological evolution of the Kerguelen Plateau. According to the most common point of view, the plateau was formed as a result of the activity of the Kerguelen hotspot; in this case, basalts should be considered the main building material, which is not only the foundation of the plateau, but also the entire vast igneous province, including the tracer ridges. The results of a geological interpretation of DSS data and chemical analysis of basalts, however, show the presence of a thick layer of continental crust, no less than $15 \mathrm{~km}$, homogeneous along the strike in the section of the Kerguelen Plateau. It is quite obvious, therefore, that the igneous complex formed by basalts is the upper structural level overlapping the Archean basement of a large fragment of the Gondwana continent.

As can be concluded from an analysis of seismic sections and geological sections exposed by deep-sea drilling, the mobile liquid magmas of the basic composition penetrated along faults into the enclosing rock in the form of sills and dikes and periodically repeated outpourings of lavas onto the day surface easily spread over it, covering significant areas. The rocks exposed on the day surface were subjected to physical weathering, with the formation of a weathering crust of the so-called boies, which, after some time, were covered by the newly erupted material. Such magmatic processes on the plateau are not an exceptional phenomenon but, on the contrary, confirm the existence of the so-called basalt "flood," which covered significant areas of the Indian Ocean from the end of the Early Cretaceous to the end of the Late Cretaceous.

The least altered tholeiitic basalts on the Kerguelen Plateau were uncovered by wells ODP-749 and ODP-750 (southern part of the plateau). Their ages, determined by the ${ }^{40} \mathrm{Ar} /{ }^{39} \mathrm{Ar}$ method, are 109 and $118 \mathrm{Ma}$, respectively. A decrease in the age of basalts is traced from south to north. Thus, in well ODP-1136 (southern part of the plateau), the age of the exposed basalts is $105 \mathrm{Ma}$, the age in well 1137 (Elan Bank) is $74 \mathrm{Ma}$, basalts in well 1138 (central part) are 94-Maold; and, in well 1140 (northern part), they are 35-Maold (Coffin, 2000). Magmatism lasted from 38 to $1 \mathrm{Ma}$ in different places of Kerguelen Island (Udintsev, 1987). However, the revealed chronological trend of volcanic activity can be accepted with a certain degree of convention, given that the lower lava flows are older than the upper ones. The lowest (dated) lava flow in well 1138 was 22 nd from the top, in well 1137 it was 10 th, and in well 1140 it was only 6th. The most ancient age of the basalts, the other hand, was determined in well 1136, where only three lava flows were opened. Consequently, basalt dating provides infor- mation on a specific phase of basalt eruption in the area of a particular deep-water well.

Structure of East Antarctica continental margin and the adjacent eastern part of the African-Antarctic megadepression. The morphostructural analysis of this region was carried out taking into account the map of the depths of the acoustic basement, where the structural features of the basement of the African-Antarctic megadepression, overlapped by a sedimentary cover, were first shown (see Fig. 5). Several depocenters (Gunnerus, Conrad, and Enderby basins, where the acoustic basement is lowered to depths of 7.5, 7.0, and $7.5 \mathrm{~km}$, respectively) were distinguished within the megadepression. Basement depth within the Valdivia Plain does not exceed $5.5 \mathrm{~km}$. The depth of the acoustic foundation in the Crozet Basin was not calculated.

The above basins are separated by relatively raised blocks of the basement, structural bridges, which are a direct continuation of the basement of the continental margin of Antarctica. The map clearly shows that such bridges can be traced from Enderby Land in two directions. The first, northwestern, flanks the Conrad Basin from the south, and the second extends northward, providing a structural link to the Elan Bank and separating the Conrad and Enderby Basins. The structural bridge between the Kerguelen Plateau and East Antarctica serves as a barrier separating the sedimentary basins of the African-Antarctic and AustralianAntarctic megadepressions. Thus, the basins of Gunnerus, Konrad, Enderby and the basement protrusions between them form a mosaic-block tectonic map of the transition zone, which was laid on the continental crust and experienced a subsidence to present depths in the course of evolution.

The structural geometry of the transition zone, taking into account the characteristic features of the passive continental margin of East Antarctica, such as the absence of listric faults (which are markers of crust extension), traces of volcanic activity, and complete aseismicity, does not correspond to the concept of its riftogenic origin. In this regard, it can be noted that the identification of the "pan-Antarctic rift" by Houtz (1978), which he believed to be the cause of the initial split of Antarctica and the Indian subcontinent, is not supported by factual material.

Enderby sedimentary basin structure. The structure and evolution of this basin can be inferred from the core of wells ODP-738, ODP-744, ODP-749, and IODP-1137, as well as from CMP sections and DSS data (see Figs. 3a, 5, 6-8). The Enderby Basin is an enclosed depression, the subsidence of which was compensated by the accumulation of $4-5 \mathrm{~km}$ thick sedimentary strata. The seismic CMP sections (see Fig. 6) show that the northern side of the basin was laid on the Kerguelen Plateau basement, which gently slopes towards the depocenter. Judging by the section of borehole no. 749 (see Fig. 7) and dredging carried out on the Banzare Bank (Ramsay et al., 1986), the 


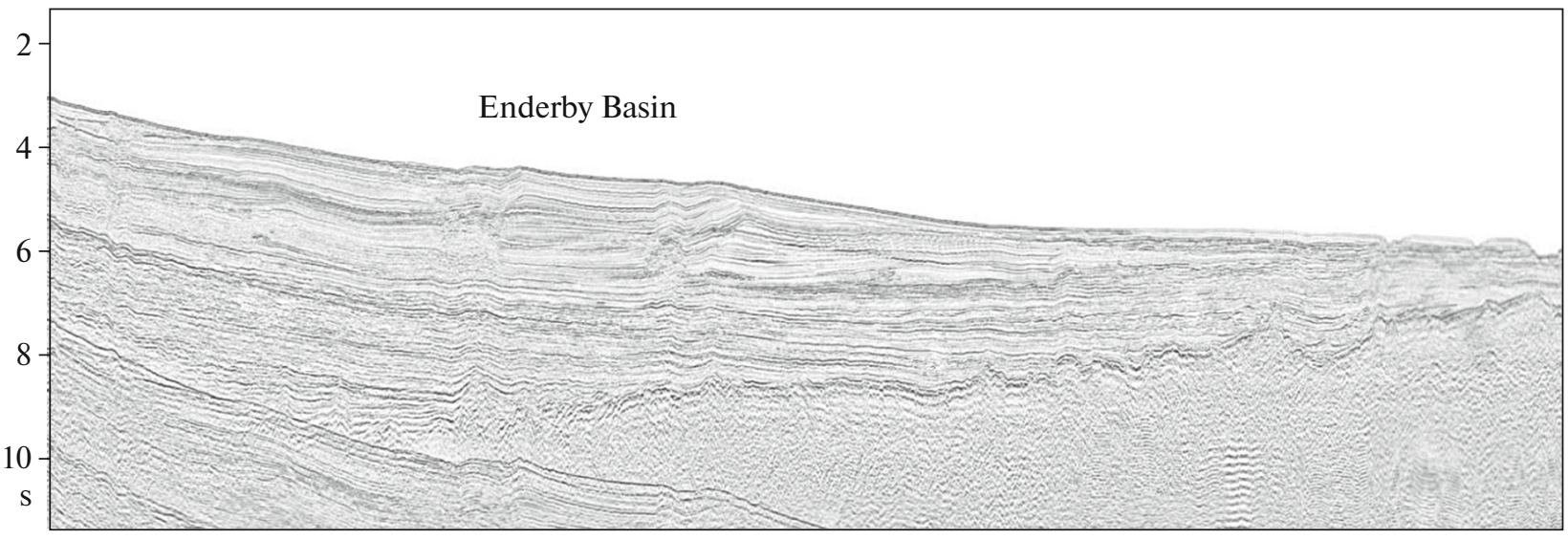

$73^{\circ} 00^{\prime} \mathrm{E}$;

(b)

$68^{\circ} 00^{\prime} \mathrm{E}$;

$66^{\circ} 30^{\prime} \mathrm{S}$

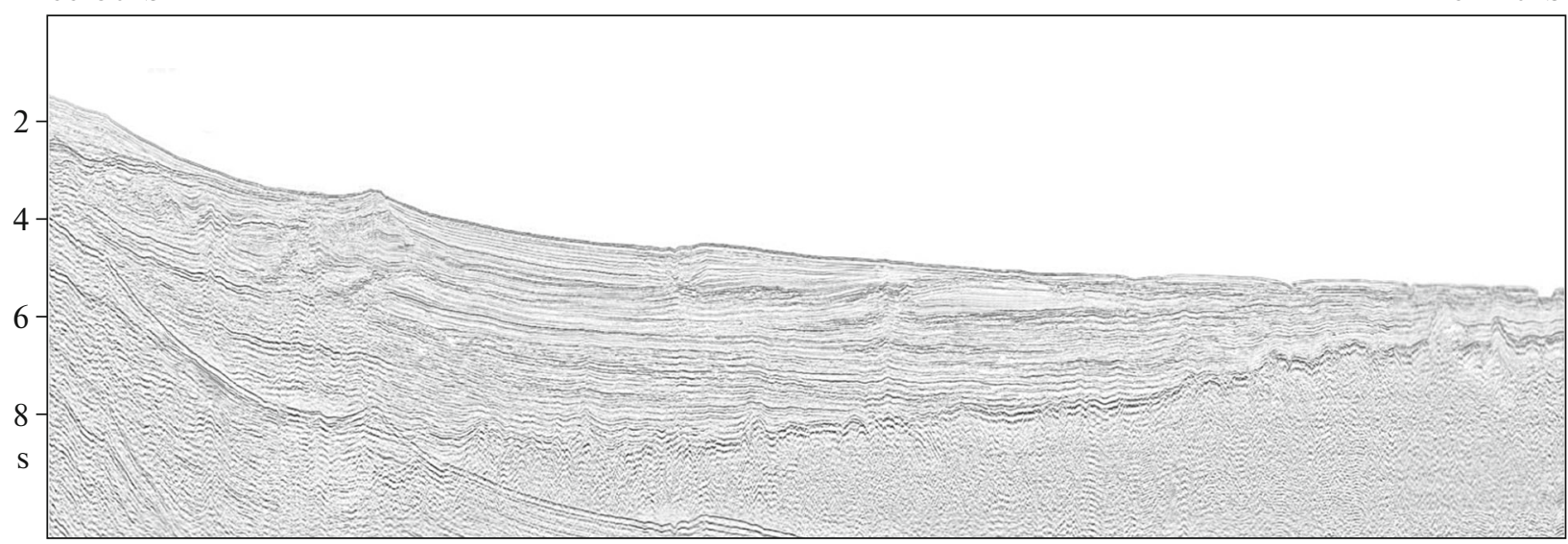

$76^{\circ} 00^{\prime} \mathrm{E}$;

(c)

$78^{\circ} 07^{\prime} \mathrm{E}$;

$65^{\circ} 08^{\prime} \mathrm{S}$

$61^{\circ} 40^{\prime} \mathrm{S}$

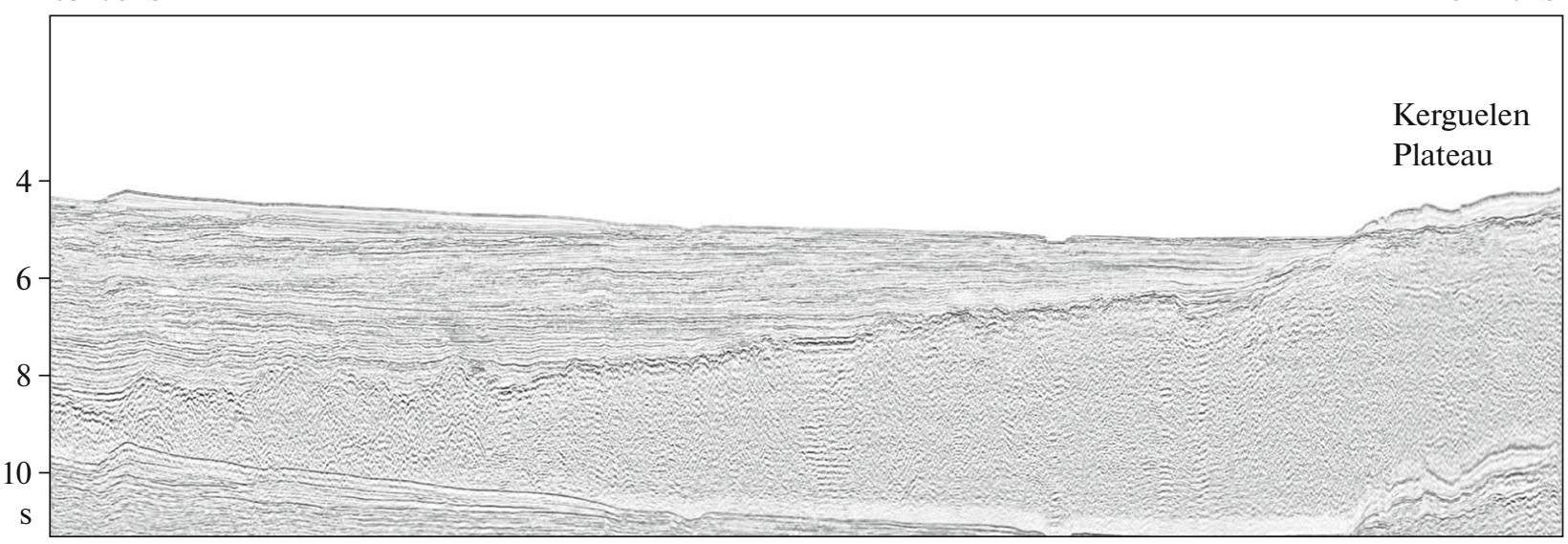

0

$100 \mathrm{~km}$

Fig. 6. CMP sections characterizing the structure of the Enderby Basin and the saddle between Kerguelen and Antarctica. (a) Section along the RAE 52-11 profile (aligned with the AWI20070100 profile), (b) section along the RAE 52-06 profile, (c) section along the RAE 52-09 profile, (d) section along the RAE 39-10 profile, (e) section along the RAE 48-08 profile (aligned with the AWI20070200 profile), and (f) section along the GA 228-10 profile. Note the overlap of the sedimentary strata on the subsided part of the basement of the Kerguelen Plateau. 
$82^{\circ} 50^{\prime} \mathrm{E}$

(d)

$82^{\circ} 45^{\prime} \mathrm{E}$;

$66^{\circ} 00^{\prime} \mathrm{S}$
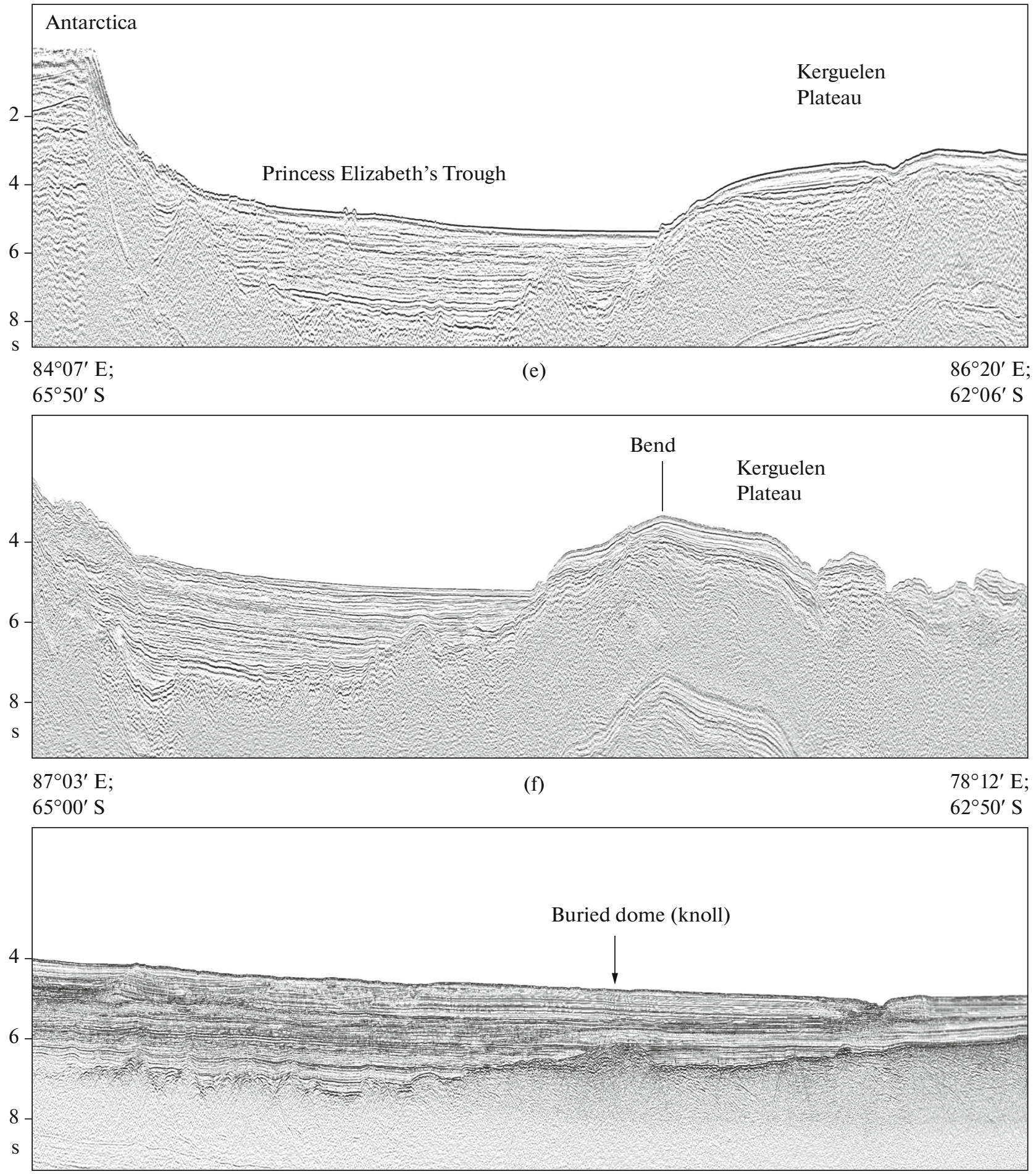

0

$100 \mathrm{~km}$

Fig. 6. (Contd.) 


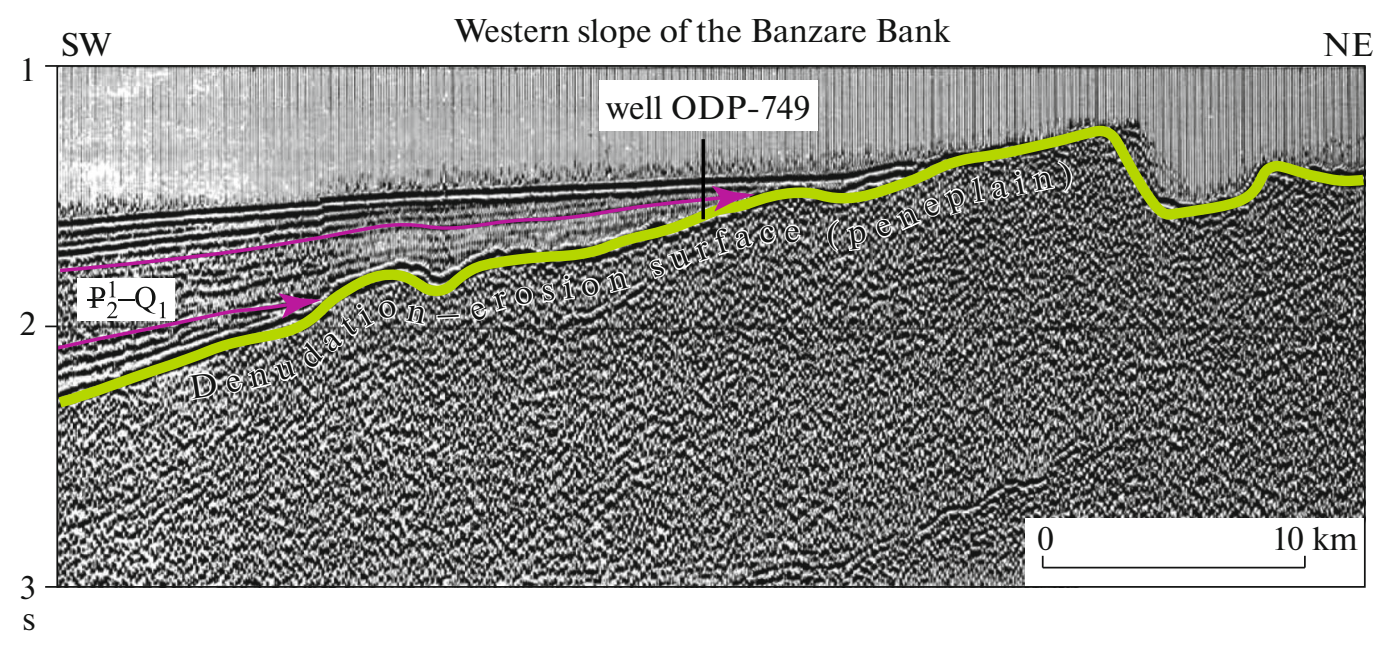

Fig. 7. Fragment of the CMP profile characterizing the structure of the western slope of the Banzare Bank in the area of well ODP-749. The arrows show the onlap of the in-phase axes, which indicates the initial phase of the basement subsidence in the Eocene.

basement corresponding to the Early Cretaceous leveling surface is composed of highly altered basalts, granites, and metamorphic rocks. The Early Eocene sedimentary strata overlapping the southwestern slope of the Banzare Bank (see Fig. 7) marks the beginning of basement subsidence and the formation of a basin. The formation was pulselike and, judging by the different thickness of the sedimentary cover, characterized by different rates of subsidence.

The subsidence of the Elan Bank to a depth of about $1 \mathrm{~km}$ is associated with the development of the Enderby Basin. An analysis of the section of well IODP-1137, drilled on the bank, indicates that, after the outflow of basalts and a long stage of development in the subaerial setting in the Late Cretaceous and Paleocene, the sedimentation regime in the Late Eocene changed to a relatively deep-water one, as is indicated by the deposition of a sequence of pelagic sediments of the Late Eocene-Pleistocene.

The DSS section of the basin (Charvis and Operto, 1999) passes through the southwestern slope of the Elan Bank, as is shown by the depth map of the acoustic basement (see Fig. 5). The subsidence of the continental crust and its thinning from 14 to $10 \mathrm{~km}$ towards the basin were established from the structure of the section, which indicates that the basin formation was occurring on the continental crust. However, the lack of direct DSS observations in the deep part of the basin leaves the question of the structure of the crust in the area of the depocenter open.

Part of the southwestern slope of the Kerguelen Plateau, which extends north of the Elan Bank, is characterized by a predominantly gentle slope. The section (see Fig. 3c) shows that the surface of the slope plunges towards the Valdivia plain. A similar pattern is observed in the area of the northern end of the plateau, where the spur of the Skiff Bank also plunges towards the submeridional passage and is unconformably overlapped by a thin layer of sediments (see Fig. 3f). The maximum subsidence of the basement of the Valdivia Plain does not exceed $5.5 \mathrm{~km}$, which indicates its structural relationship with the extensive arch uplift of the basement, where the Del Cano-Crozet and Conrad plateaus and smaller horst outliers are located. This area is characterized by tectonic fragmentation, a high amplitude of vertical dissection, and the manifestation of active volcanism (see Fig. 5).

Raggatt sedimentary basin. is the most studied basin in the region (see Fig. 8). Its structure provides information on the Late Cretaceous-Cenozoic stage of evolution of the northeastern part of the Kerguelen Plateau. An analysis of time sections made it possible to identify four regional seismostratigraphic complexes (SC) within the Raggatt sedimentary basin (RSB). The boundaries of the complexes are confined to the surfaces of unconformities, formed due to either interruptions in sedimentation or changes in the sedimentation regime.

The structure of the lower complex (4SC) is characterized by extended intense wave patterns. The convergence of the reflecting boundaries and a decrease in the thickness of the complex are observed on the sides of the basin, which indicates the syn-depositional nature of sedimentation. The maximum thickness of this complex has not been established, since the seismic records of the lower part of the section are complicated by multiple reflections; it can be assumed, however, that the thickness in the depocenter reaches $1.0 \mathrm{~s}$ (of double time).

The unconformity surfaces serve as boundaries for the overlying third complex (3SC). The lower boundary is defined by the termination of the base-discordance wave pattern. The upper boundary coincides with the erosional truncation, which is especially dis- 
(a)

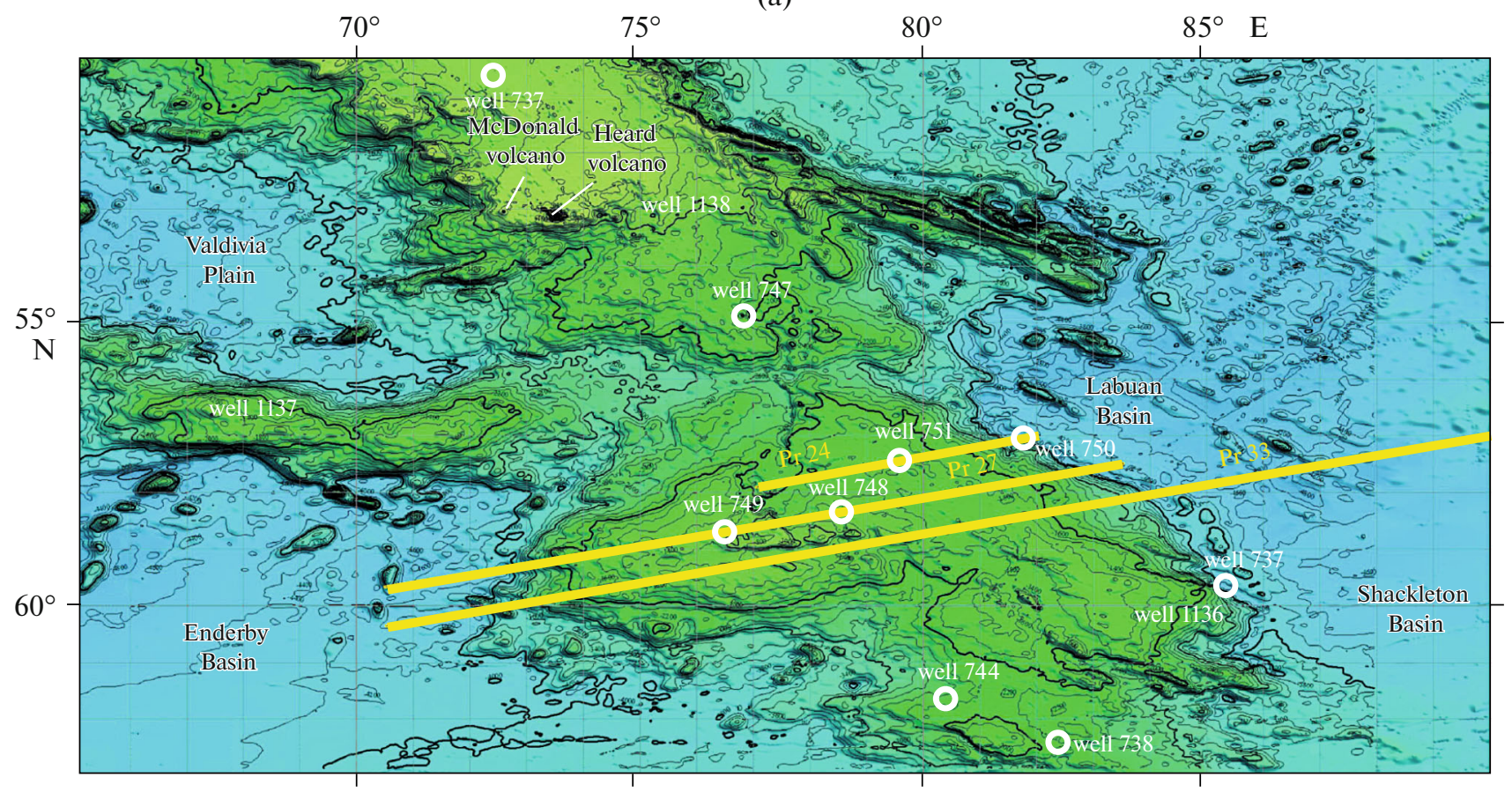

WSW

(b)

ENE

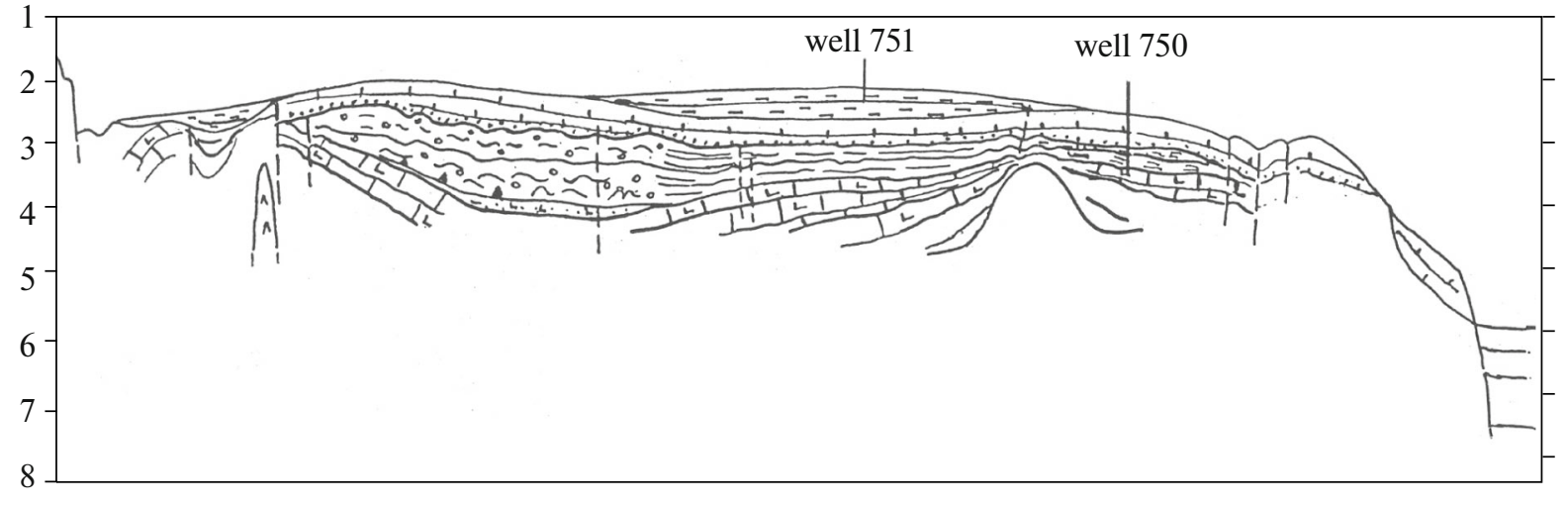

\section{WSW}

(c)

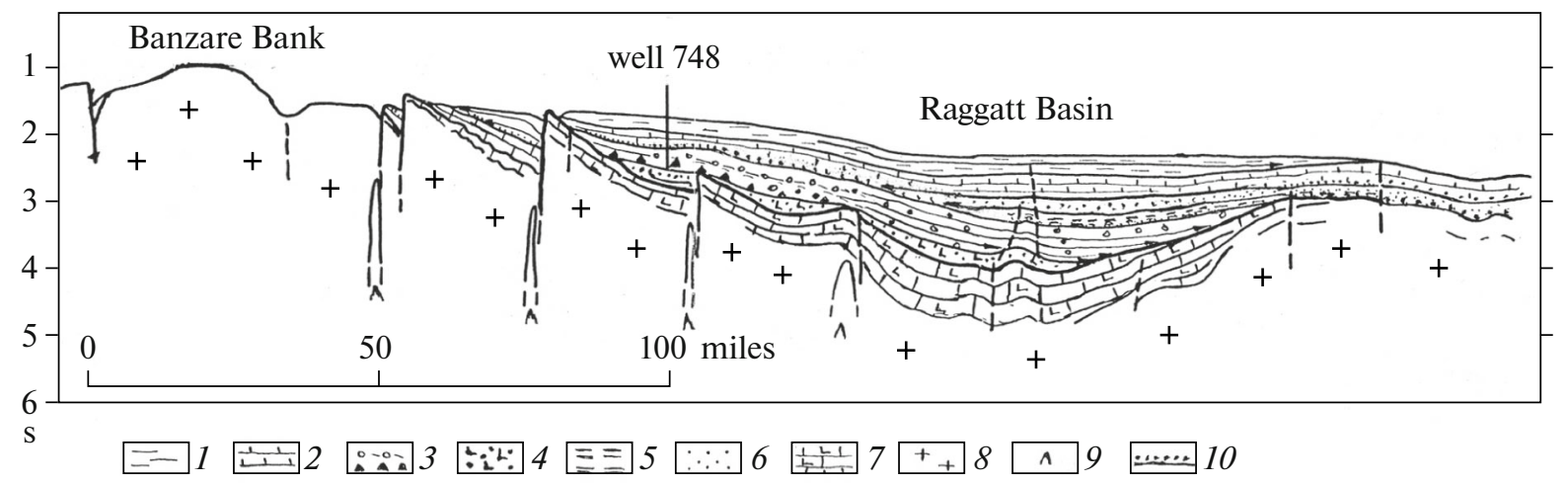

Fig. 8. (a) Bathymetric map of the central part of the Kerguelen Plateau; (b, c) seismoacoustic sections characterizing the structure of the Raggatt Basin obtained by R/V Rig Seismic along profile 24 (b) and along profile 27 (c). (b, c) (1) Silty deposits; (2) silts and chalk with silicon interlayers; (3) fluvial and littoral deposits; (4) weathered, highly altered basalts; (5) lagoon deposits; (6) shallow sandy deposits; (7) effusive rocks, lava breccia with interlayers of shallow-water limestones; (8) crystalline basement, composed of rocks of basic and acidic composition; (9) dikes, intrusives; and (10) erosional unconformity surface, boundary of the Maastrichtian-Danish break. 
tinct in the western part of the section. The lateral thickness of the third complex varies from an average 0.6 to $1.3 \mathrm{~s}$. Its internal structure is characterized by a disordered chaotic seismic record; areas with more or less ordered and extended reflective boundaries are only recorded in the lower part of the complex. These boundaries are confined to the lowered parts of the bottom of the third complex and form a separate subcomplex. Apparently, this subcomplex is composed of redeposited products of erosion of the lower (fourth) SC. Its formation at the boundary of the Early and Late Cretaceous indicates the beginning of tectonic restructuring of the basin and a change in the sedimentation regime. The upper part of the $3 \mathrm{SC}$ complex is probably composed of terrigenous rocks accumulated under conditions of compensated subsidence.

The second SC is quite clearly distinguished by its dynamic expressiveness throughout the entire seismic section. It is characterized by low-frequency parallellayered extended boundaries. The thickness of this complex is constant along the strike and is approximately $0.3-0.4 \mathrm{~s}$. The lower boundary of $2 \mathrm{SC}$ coincides with the regional unconformity traced within the entire basin.

Upper SC (1SC) has a distinctive dynamic expressiveness in seismic recording. It is characterized by high-frequency parallel extended reflections typical of silty deposits. The lower boundary of the complex is established by base discordance (overlapping), which can be traced on profile 24 ( $\operatorname{Pr} 24$ in Fig. 8a). The same profile shows that the complex has the shape of a lens (see Fig. 7). In section 27 (Pr 27), the lower boundary is established by continuous tracing from the unconformity, thus, being a hidden unconformity surface between two subhorizontal layers practically undisturbed by tectonic events. It is much easier to trace this boundary at the contact of two seismic complexes with different dynamic expressiveness. The relatively concordant occurrence of the upper two complexes apparently indicates the absence of fundamental differences in the manifestation of tectonic processes during their formation, and a change in the nature of the seismic record in this case indicates different degrees of lithification rather than a difference in petrological composition.

The conclusions inferred from the seismostratigraphic analysis of the Raggatt Basin are generally consistent with the drilling and dredging data, which make it possible to clarify the lithological-facies composition of the sedimentary cover and establish the age of the deposits, as well as determine the petrographic composition of the rocks of the acoustic basement. Dredging at the Banzare Bank raised granites, metamorphic rocks, and highly weathered basalts, which indicates the crystalline composition of the acoustic basement (Ramsay et al., 1986). The other three complexes were penetrated by drilling wells ODP-748 and
ODP-750. The first well drilled to a depth of $950 \mathrm{~m}$ and reached the rocks of the lower 3SC subcomplex. Another well penetrated $700 \mathrm{~m}$ of sediments in the eastern part of the basin and passed through the entire 3SC. The lower subcomplex, 3SC, is represented by loose and highly weathered basalts, as well as products of their weathering. The age of these deposits has not been determined; it was learned, however, that they overly unaltered basalts, dated to the Barremian, $114 \mathrm{Ma}$ ago. The outpouring of basalts at the end of the Early Cretaceous was recorded in wells ODP-738 (110 Ma BP) and ODP-744, also located in the southern part of the Kerguelen Plateau. An analysis of the core from these wells indicates that the products of destruction of basalts were overlapped after a break of $20 \mathrm{Ma}$. Consequently, the active accumulation of 3SC deposits began at the turn of the Early and Late Cretaceous due to the tectonic restructuring that took place in the southern part of the plateau at that time.

In the section exposed by well 748 (see Fig. 8), the $3 \mathrm{SC}$ complex is represented by a 500-m stratum of fluvial and littoral deposits dated to the Turonian-Late Maastrichtian; that is, a subaerial setting existed over a vast area in the southern part of the plateau throughout the Late Cretaceous. There is a 6-Ma hiatus in sedimentation at the top of this stratum, which corresponds to the Danian Age at the Cretaceous-Paleocene boundary. Well 750 opened a $50-\mathrm{m}$ layer of lagoon and shallow-water deposits containing charcoal, fossilized and ferruginous remains of vegetation, and watered mudstones with interlayers of sands and conglomerates above strongly altered basalts corresponding to the lower subcomplex 3SC. The age of these sediments has not been established. Up the section, there is a $250-\mathrm{m}$ sequence of shallow-water carbonate deposits with significant glauconite content. The age of these accumulations is determined as the Turonian (Cenomanian?)-Maastrichtian.

Thus, the correlation of all drilling data makes it possible to subdivide the 3SC complex into lithological (stratigraphic) units and trace their succession laterally from west to east. In the lower part of the complex, fluvial facies are replaced by lagoon-littoral ones, while littohal deposits give way to shallow-water ones in the upper part. Such a succession of facies observed up the section indicates the progressive transgression in this region in the Late Cretaceous. Considering that shallow-water Early Cretaceous deposits are present in the section of wells 738 and 744 and that they were formed after a long hiatus, it can be assumed that the transgressive phase covered a significant part of South Kerguelen in the Late Cretaceous.

According to drilling data, the thickness of the 2SC complex varies from $200 \mathrm{~m}$ (borehole 748) to $320 \mathrm{~m}$ (borehole 750). The complex is represented by relatively deep-water (bathyal) sediments, mainly nanofossil silts. The age of these sediments varies from the Paleocene (or Late Paleocene in well 748) to the Mid- 
dle Eocene. The lower boundary of 2SC coincides with the regional unconformity, which corresponds to a hiatus in sedimentation established in the Raggatt Basin at the Cretaceous-Paleogene boundary. There is no break outside the basin.

The Upper SC (1SC) is composed of typically late Eocene-Pleistocene marine deep-water sediments, represented by a $200-\mathrm{m}$ stratum of nanofossil silts overlain by a 30-m layer of Pliocene-Pleistocene silts (well 748).

An analysis of the seismic and stratigraphic data shows that the Raggatt Basin experienced two main phases in development during the Cretaceous-Cenozoic. The first occurred before the MaastrichtianEarly Paleogene and was characterized by a subaerial regime; the second phase started from the end of the Paleocene and was characterized by relatively deepwater conditions. Consequently, it can be assumed that the structural rearrangement in this region occurred as a result of the tectonomagmatic activation phase at the turn of Cretaceous and Paleogene, when the Labuan and Shackleton basins were laid due to the differentiated block movements and the Kergelen Plateau was separated from the southwestern flank of the Australian-Antarctic Rise.

Structure of the southern Kerguelen Plateau and adjacent Labuan and Shackleton depressions. As noted above, the slopes of the Banzare horst block carry the outcrops of strongly altered weathered basalts, granites, and metamorphic rocks (Ramsay et al., 1986). Obviously, horst outliers, widely developed in the southern part of the Kerguelen Plateau (Korint Bank, Umitaka-Maru Ridge, etc.), are composed of similar rocks. Such blocks are relict fragments of an ancient flattening surface that has evolved over a long period of tens of millions of years. As a result of denudation processes, they acquired a characteristic domed shape (knoll). Being subjected to erosion-denudation processes, the domes served as a source of detrital material and for spreading of deluvial-alluvial material. The formation of a $20-\mathrm{m}$ stratum of fluvial deposits, exposed by drilling at the Elan Bank, is associated with the erosion of one of these large basement protrusions.

As was shown by the structure of seismoacoustic sections, domelike forms that developed in the southern part of the Kerguelen Plateau are also widespread beyond its borders. Domes, partially or completely covered by a sediments, are found, e.g., in the area of the saddle structure connecting Kerguelen and Antarctica (see Fig. 6, Pr 6) A number of knolls was identified also in the Labuan and Shackleton basins: Ruser Knoll, (depth $3.3 \mathrm{~km}$ ), Meinardus Knoll (depth $2.7 \mathrm{~km}$ ), Bidling Maier Knoll (depth $2.3 \mathrm{~km}$ ), Luyken Knoll (depth $2.9 \mathrm{~km}$ ), Moseley Knoll (depth $3.0 \mathrm{~km}$ ), and others (Vanney and Johnson, 1982).

The distribution area of these structures made it possible to establish that the leveling surface extended beyond the modern outlines of the southern part of the
Kerguelen Plateau southeast to the Bruce Plateau (Bank) (see Fig. 2) and southward to the continental margin of Antarctica, where its immediate continuation is the relict leveling surface, the so-called Monsoon peneplain (Kurinin and Grikulov, 1980).

In this regard, it should be noted that large domelike structures are widely developed on the northern slope of the West Australian Ridge, which may indicate the regional distribution of the peneplain on the land area that existed in the Cretaceous period in the eastern part of the Indian Ocean (Illarionov et al., 2020) (see Fig. 2).

Since the basement structure of the southern part of the Kerguelen Plateau contains a thick layer of continental crust and the Labuan and Shackleton basins were laid on the subsided blocks of the Kerguelen Plateau, one may expect the presence of a transitional crust, largely reworked by tectonomagmatic processes, as well as preserved fragments of the granite-gneiss layer in the structure of these basins. This was confirmed by the dredging carried out on one of the large horst basement outcrops in the Labuan Basin, when granite-gneiss rock samples weighing more than $1 \mathrm{t}$ were raised $\left(55^{\circ} 18^{\prime} \mathrm{S}, 83^{\circ} 04^{\prime} \mathrm{E}\right)$ (Montigny et al., 1993) (Fig. 9). The pronounced southeastern trend of faults governing the strike of horst-graben structures developed in the Labuan and Shackleton basins indicates a structural connection between the Kerguelen Plateau and the Antarctic continent (see Fig. 9).

\section{CONCLUSIONS}

The material presented in the article allows the following conclusions to be drawn.

(1) In terms of structure, the southern Indian Ocean can be divided into four tectonic taxa of the first order: (1) the Crozet Basin; (2) the eastern part of the African-Antarctic megadepression; (3) the Kerguelen Plateau; and (4) a vast four-way dip basement uplift carrying the Del Cano-Crozet Plateau, the Conrad Plateau, the Valdivia Abyssal Plain, and a number of small horst blocks.

(2) The Conrad, Del Cano-Crozet, and Kerguelen plateaus are similar in structure to the Madagascar Ridge, which is a structural continuation of the island of Madagascar. In the Late Cretaceous and Paleogene, they were parts of a vast land mass that extended from Madagascar to the eastern part of mainland Antarctica.

(3) The development of riftogenic processes and the formation of the middle West Indian Ridge at the end of the Miocene led to crushing into blocks and the significant processing of the crust of this ancient continental massif by tectonomagmatic processes.

(4) Both the structure of the Kerguelen volcanic island and the results of a geochemical analysis of rock samples collected on the island indicate that it was formed on the ancient continental crust. 
(a)
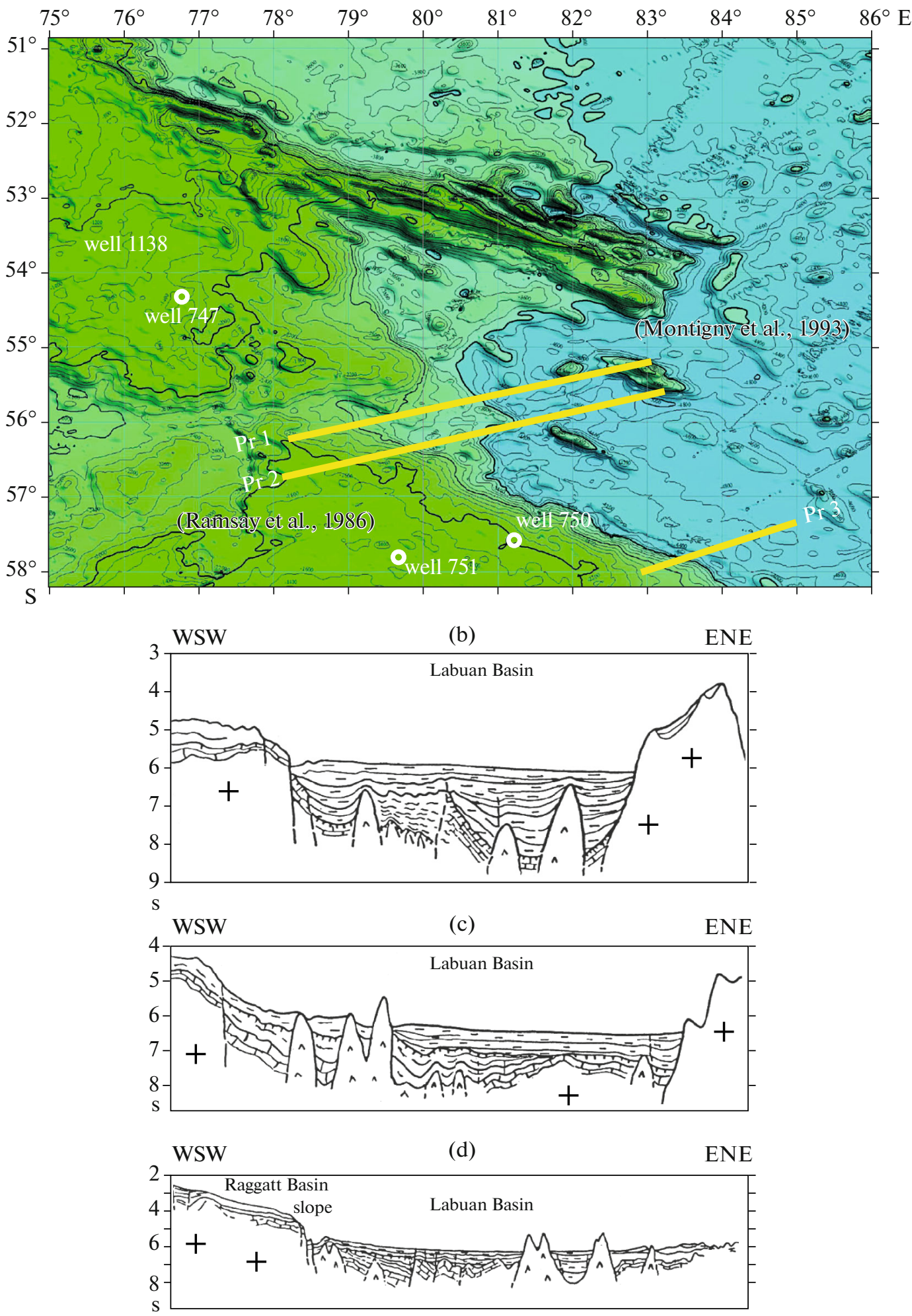

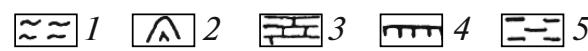

Fig. 9. (a) Bathymetric map of the Williams Ridge and the Labuan Basin and (b, c, d) geological and geophysical sections of the Labuan basin along profiles 15 (b), 17 (c), and 33 (eastern part) (d). (a) Profiles of R/V Rig Seismic (Ramsay et al., 1986): (Pr 1) profile 15, ( $\operatorname{Pr} 2$ ) profile 17, and (Pr 3) profile 33 (eastern part). Triangles are dredging sites (Ramsay et al., 1986; Montigny et al., 1993). (b-d) (1) Unsorted material from the Kerguelen Plateau, (2) dikes and other magmatic bodies, (3) subsided blocks of the Kerguelen Plateau with preserved Late Cretaceous rocks, (4) regional unconformity surface, and (5) deep-water facies of the post-Eocene age. 
(5) The crust of the Kerguelen Plateau has a relatively homogeneous structure along the strike. A thick, at least $15 \mathrm{~km}$, layer of continental crust can be traced in the crust section, which undoubtedly indicates the continental nature of the Kergelen Plateau.

When the article was being prepared for submission to the editors, the results of the latest studies carried out in the North Atlantic in the area of Iceland had been published (Foulger et al., 2021). The authors of the article showed that the crust thickness of the island is $40 \mathrm{~km}$ and it cannot be composed of an oceanic crust 6 times larger than usual. Geochemical research data show that Iceland is not a hot spot. In the light of these results, the problem of the Kerguelen hotspot acquires special significance and undoubtedly requires additional research in the area of Kerguelen archipelago to clarify the structure of the lower crust and the depth of the Moho discontinuity.

To do so, one should carry out a detailed DSS survey with a large number of bottom stations, which is the most suitable method for solving such issues. Such a survey is quite feasible too, since progress has recently affected the technology of observations with bottom stations; they have become more compact, long-term, and autonomous, and their maintenance requires far fewer human resources, such as the selffloating bottom GNS seismographs that have been developed and used successfully all over the world by Ilyinsky (Ilyinsky et al., 2018, 2019).

\section{ACKNOWLEDGMENTS}

We thank N.I. Pavlenkova, I.E. Lomakin, E.A. Dolginov, and O.Yu. Ganzha for their valuable advice when discussing the article.

\section{FUNDING}

This work was carried out as part of state assignment no. 0144-2019-0011 for the Schmidt Institute of Physics of the Earth, Russian Academy of Sciences.

\section{CONFLICT OF INTEREST}

The authors declare that they have no conflicts of interest.

\section{REFERENCES}

Beaman, R.J. and O'Brien, P.E., Kerguelen plateau bathymetric grid, Canberra: Australia, 2011, Geosci. Aust. Rec. 2011/22.

Bénard, F., Callot, J.-P., Vially, R., Schmitz, J., Roest, W., Patriat, M., and Loubrieu, B., The Kerguelen plateau: Records from a long-living/composite microcontinent, Mar. Petrol. Geol., 2010, vol. 27, no. 3, pp. 633-649.

Borisova, A.Y., Nikulin, V.V., Belyatsky, B.V., Ovchinikova, G.V., Levsky, L.K., and Sushchevskaya, N.M., Late alkaline laves of the $\mathrm{Ob}$ ' and the Lena seamounts of Conrad rise (Indian Ocean): Geochemistry and characteristics of mantle sources, Geochem. Int., 1996, vol. 34, pp. 503-517.

Borisova, A.Y., Nikogosian, I.K., Scoates, J., Weis, D., Damasceno, D., Shimizu, N., and Touret, J.L.R., Melt, fluid and crystal inclusions in olivine phenocrysts from Kerguelen plume-derived picritic basalts: Evidence for interaction with the Kerguelen plateau lithosphere, Chem. Geol., 2002, vol. 183, pp. 195-220.

Borisova, A.Y., Faure, F., Deloule, E., Grégoire, M., Béjina, F., de Parseval, P., and Devidal, J.L., Lead isotope signatures of Kerguelen plume-derived olivine-hosted melt inclusions: Constraints on the ocean island basalt petrogenesis, Lithos, 2014, vol. 198-199, pp. 153-171.

Borisova, A.Y., Bohrson, W.A., and Gregoire, M., Origin of primitive ocean island basalts by crustal gabbro assimilation and multiple recharge of plume-derived melts, Geochem., Geophys., Geosyst., 2017, vol. 7, pp. 1-47.

Borissova, I., Coffin, M.F., Charvis, P., and Operto, S., Structure and development of a microcontinent: Elan Bank in the Southern Indian ocean, Geochem., Geophys., Geosyst., 2003, vol. 4, no. 9, pp. 1-16.

Cande, S. and Mutter, J., A revised identification of the oldest seafloor spreading anomalies between Australia and Antarctica, Mar. Geol., 1982, no. 58, pp. 151-160.

Charvis, P. and Operto, S., Structure of the cretaceous Kerguelen volcanic province (Southern Indian Ocean) from wide-angle seismic data, J. Geodyn., 1999, no. 28, pp. 51-71.

Crawford, A.R., India, Ceylon and Pakistan: New age data and comparisons with Australia, Nature, 1969, vol. 223, pp. 380-384.

Curray, J.R. and Moor, D.G., Sedimentary and tectonic processes in the Bengal deep-sea fan and geosyncline, in The Geology of Continental Margins, Burk, A. and Drake C.L., Eds., Berlin: Springer, 1974, pp. 618-627.

Davies, H.L., Sun, S., Frey, F.A., et al., Basalt basement from the Kerguelen plateau and the trail of a Dupal plume, Contrib. Min. Petrol., 1989, vol. 103, pp. 457469.

Davis, J.K., Lawver, L.A., Norton, J.O., Dalziel, J.W., and Gahagan, L.M., The crustal structure of the Enderby basin, East Antarctica, Mar. Geophys. Res., 2018, vol. 40, pp. 1-16.

Dietz, R., Passive continents, spreading sea floors and collapsing continental rises, Am. J. Sci., 1966, vol. 264, pp. 177-193.

Dietz, R.S. and Holden, J.C., Pre-Mesozoic oceanic crust in the Eastern Indian Ocean, Nature, 1971, vol. 229, pp. 309-312.

Dosso, L., Vidal, P., Cantagrel, J.M., Lameyre, J., Mariot, A., and Zimine, S., "Kerguelen continental fragment or oceanic "island?": Petrology and isotopic geochemistry evidence, Earth Planet. Sci. Lett., 1979, vol. 43, pp. 46-60.

Dosso, L., Bougault, H., Beuzart, P., Calvez, J.-Y., and Joron, J.-L., The geochemical structure of the SouthEast Indian ridge, Earth Planet. Sci. Lett., 1988, vol. 88, nos. 1-2, pp. 47-59.

Duncan, R.A., Falloon, T.J., Quilty, P.G., and Coffin, M., $F$ widespread Neogene volcanism on Central Kerguelen plateau, Southern Indian Ocean, Aust. J. Earth Sci., 2016, vol. 63, no. 4, pp. 379-392. 
Falvey, D.A., Sea-floor spreading in the Warton basin (North-East Indian Ocean and the breakup of Eastern Gondwanaland), Aust. Petrol. Explor. Assoc. J., 1972, vol. 12, pp. 86-88.

Fedorov, L.V., Ravich, M.G., and Hofmann, J., Geologic comparison of Southeastern Peninsular India and Sri Lanka with a part of East Antarctica (Enderby land, MacRobertson land, and Princess Elizabeth land), in Antarctic Geoscience, Ed., Craddock, C., Madison: Univ. of Wisconsin Press, 1982, pp. 73-78.

Foulger, G., Gernigon, L., and Geoffroy, L., "Icelandia," Geol. Soc. Am. Spec. Pap., 2021, vol. 553, pp. 1-12.

Francis, T.J.G. and Raitt, R.W., Seismic refraction measurements in Southern Indian ocean, J. Geophys. Res., 1967, vol. 72, pp. 3015-3041.

Frey, F.A., Coffin, M.F., Wallace, P.J., Weis, D., Zhao, X., Wise, S.W., Wähnert, V., Teagle, D.A.H., Saccocia, P.J., Reusch, D.N., Pringle, M.S., Nicolaysen, K.E., Neal, C.R., Muller, R.D., Moore, C.L., et al., Origin and evolution of a submarine large igneous province: the Kerguelen plateau and Broken Ridge, Southern Indian ocean, Earth Planet. Sci. Lett., 2000, vol. 176, no. 1, pp. 73-89.

Frey, F.A., Weis, D., Borisova, A.Y., and Xu, G., Involvement of continental crust in the formation of the cretaceous Kerguelen plateau: New perspectives from ODP leg 120 sites, J. Petrol., 2002, vol. 43, no. 7, pp. 12071239.

Frolova, T.I., The role of magmatic processes in the transformation of continental crust, Byull. MOIP: Otd. Geol., 2001, vol. 36, no. 4, pp. 7-24.

Fuchs, K. and Muller, G., Computation of synthetic seismograms with the re-activity method and comparison with observations, Geophys. J. R. Astron. Soc., 1971, vol. 23, pp. 417-433.

Gibbons, A.D., Whittaker, J.M., and Muller, R.D., The breakup of East Gondwana: Assimilating constraints from cretaceous ocean basins around India into a bestfit tectonic model, J. Geophys. Res., 2013, vol. 118, pp. 808-822.

Giret, A., Typology, evolution, and origin of the Kerguelen Plutonic Series, Indian ocean: A review, Geol. J., 1990, vol. 25 , pp. 239-247.

Gohl, K., Leitchenkov, G.L., Parsiegla, N., Ehlers, B.-M., Kopsch, C., Damaske, D., Guseva, Y.B., and Gandyukhin, V.V., Crustal types and continent-ocean boundaries between the Kerguelen plateau and Prydz Bay, East Antarctica, 10th Int. Symp. on Antarctic Earth Sci., U.S. Geol. Surv. Natl. Acad., 2007, USGS OF-20071047: extended abstract 038.

Goslin, J., Résultats de gravimétrie sur les monts sous-marins du Marion Dufresne, de la Lena et de l'Ob (Océan Indien austral), C. R. Acad. Sci., Paris, 1979, vol. 288, pp. 241-244.

Grégoire, M., Mattielle, N., Nicollet, C., Cottin, J., Leyritt, H., Weis, D., Shimizu, N., and Giret, A., Oceanic mafic granulite xenoliths from the Kerguelen archipelago, Nature, 1994, vol. 367, pp. 360-361.

Grégoire, M., Cottin, J.Y., Giret, A., Mattielli, N., and Weis, D., The meta-igneous granulite xenoliths from Kerguelen archipelago: Evidence of a continent nucle- ation in an oceanic setting, Contrib. Min. Petrol., 1998, vol. 133, pp. 259-283.

Hedge, C.E., Watkins, N.D., Hildreth, R.A., and Doering, W.P., ${ }^{87} \mathrm{Sr} /{ }^{86} \mathrm{Sr}$ ratios in basalts from islands in the Indian ocean, Earth Planet. Sci. Lett., 1973, vol. 21, pp. 29-34.

Heezen, B. and Tharp, M., Physiography of the Indian ocean, Philos. Trans. R. Soc., A, 1966, vol. 259, pp. 137149.

Hoernle, K., Hauff, F., Werner, R., Bogaard, P., Gibbons, A.D., Conrad, S., and Muller, R.D., Origin of Indian Ocean Seamount Province by shallow recycling of continental lithosphere, Nat. Geosci., 2011, vol. 4, pp. 883-887.

Houtz, R., Continental margins of Antarctica: Pacific-Indian sectors, in The Geology of Continental Margins, Burk, A. and Drake C.L., Eds., Berlin: Springer, 1974, pp. 655-658; Moscow: Mir, 1978, vol. 2, pp. 367-371.

Houtz, R., Hayes, D., and Markl, R., Kerguelen plateau bathymetry, sediment distribution and crustal structure, Mar. Geol., 1977, vol. 25, pp. 95-130.

Il'inskii, D.A., Roginskii, K.A., and Ganzha, O.Yu., Geophysical technologies for studying the processes of deep oil formation, Vestn. Gos. Univ. Morsk. Rechn. Flota im. Admirala S.O. Makarova, 2018, vol. 10, no. 5, pp. 936950.

Il'inskii, D.A., Ginzburg, A.A., Voronin, V.V., Ganzha, O.Yu., Manukin, A.B., and Roginskii, K.A., Creation of newgeneration digital bottom seismic stations: The present state and future outlook, Geoekol. Inzh. Geol., Gidrol., Geokriol., 2019, no. 2, pp. 87-101.

Ilinsky, D.A., Alekseev, A.E., Ganzha, O.Yu., Simikin, D.E., and Ojha, M., Use of fiber optic communication lines with a phase-sensitive reflectometer for recording seismic signals, Seismic Instrum., 2021, vol. 57, no. 4, pp. 231-248.

https://doi.org/10.3103/S0747923921030051

Illarionov, V.K. and Boiko, A.N., Geological structure and specific features of Mez-Cenozoic of the southern part of the East-Indian Ridge, Indian Ocean, Geol. Polezn. Iskop. Mirovogo Okeana, 2018, vol. 14, no. 3, pp. 62-71.

Illarionov, V.K., Boiko, A.N., and Udintsev, G.B., The ocean floor morphostructure of the Bay of Bengal (Indian Ocean) and the problem of its origin, Izv., Phys. Solid Earth, 2016, vol. 52, no. 3, pp. 382-398.

Illarionov, V.K., Boiko, A.N., Borisova, and A.Yu., A new model of the Ninety East Ridge formation, Indian Ocean, Izv., Atmos. Ocean. Phys., 2019, vol. 55, no. 11, pp. 1787-1802. https://doi.org/10.1134/S0001433819110203

Illarionov, V.K., Boiko, A.N., Borisova, and A.Yu., West Australian Ridge (Indian Ocean): Microcontinent or Large Igneous Province?, Izv., Atmos. Ocean. Phys., 2020, vol. 56, no. 10, pp. 1247-1272. https://doi.org/10.1134/S0001433820100059

Ishchenko, K.V. and Katsuk, O.K., Material characteristics of bottom rocks in the Lena and $\mathrm{Ob}$ banks region (South Indian Ocean), in Tez. dokl. 10-i Mezhdunar. shkoly morskoi geologii (Abstracts of Presentations at the 10th International School of Marine Geology), Moscow, 1992, vol. 2, p. 177. 
Ivanov, V.E. and Vakaryuk, V.T., The relief and features of the geological structure of the West-Indian Ridge (Indian Ocean), Geol. Zh., 1991, no. 6, pp. 54-61.

Johnson, B.D., Powell, C.Mc.A., and Veevers, J.J., Spreading history of the Eastern Indian ocean and Greater India's northward flight from Antarctica and Australia, Geol. Soc. Am. Bull., 1976, vol. 87, pp. 15601566.

Kadmina, I.N., Kurinin, R.G., Masolov, V.N., and Grikurov, G., Antarctic crustal structure from geophysical evidence: A revive, in Antarctic Earth Science: Proc. of the 4th Inter. Symp., 16-20 August 1982, Adelaide, South Australia, Oliver, R.L., James, P.R., and Jago, J.B., Eds., Cambridge Univ. Press, 1983, pp. 498-502.

Kanao, A., Suvorov, B.D., Yamashitac, M., and Mishenkin, B., Crustal structure and tectonic evolution of Enderby land, East Antarctica, as revealed by deep seismic surveys, Tectonophysics, 2014, vol. 627, pp. 38-47.

Kent, R.W., Pringle, M.S., Muller, R.D., Saunders, A.D., and Ghose, N.C., 40Ar/39Ar geochronology of the Rajmahal basalts, India, and their relationship to the Kerguelen plateau, J. Petrol., 2002, vol. 43, no. 7, pp. $1141-1153$.

Kónnecke, L.K., Coffin, M.F., Charvis, P., Symonds, P.A., Ramsay, D., and Bernadel, G., Crustal structure of Elan bank, Kerguelen plateau, EOS, Trans. Am. Geophys. Union, Fall Meeting, 1997, F712, T51B-3.

Kurinin, R.G. and Grikulov, G.E., The structure of the rift zone of the Lambert glacier, Tr. Sov. Antarkt. Eksped., 1980, vol. 70, pp. 76-86.

Laughton, A.S., Matthews, D.H., and Fisher, R.L., The structure of the Indian ocean, in The Sea, Maxwell, A.E., Ed., New York: Wiley-Interscience, 1970, vol. 4, pp. 543-586.

Leichenkov, G.L., Guseva, Yu.B., Gandyukhin, V.V., Gohl, K., Ivanov, S.V., Golynskii, A.V., and Kazankov, A.Yu., Crustal tectonics and depositional history in the Southern Indian Ocean (East Antarctica: Cooperation Sea, Davis Sea, Kerguelen Plateau), in Rossiiskie issledovaniya po programmers MPG 2007/2008. Stroenie $i$ istoriya razvitiya litosfery (Russian Investigations on the 2007/2008 International Polar Year Program: The Lithosphere Structure and History of Development), Leonov, Yu.G., Ed., Moscow: Paulsen Editions, 2010, pp. 9-38.

Leichenkov, G.L., Guseva, Yu.B., Gandyukhin, V.V., and Ivanov, S.V., Stroenie zemnoi kory $i$ istoriya geologicheskogo razvitiya osadochnykh basseinov Indookeanskoi akvatorii Antarktiki (The Structure of the Earth's Crust and the History of the Geological Development of Sedimentary Basins in the Indian Ocean Water Area of Antarctica), St. Petersburg, 2015.

Leichenkov, G.L., Dubinin, E.P., Grokholsky, A.L., and Agranov, G.D., Formation and evolution of microcontinents of the Kerguelen Plateau, Southern Indian Ocean, Geotectonics, 2018, vol. 52, no. 5, pp. 499-515. https://doi.org/10.1134/S0016852118050035

Leichenkov G.L., Galushkin Yu.I., Guseva Yu.B., Gandyukhin V.V., Dubinin E.P. Crustal structure, tectonic subsidence, and lithospheric stretching of the Princess Elizabeth Trough Basin, East Antarctica, Geotectonics, 2019, vol. 53, no. 6, pp. 726-737.

https://doi.org/10.1134/S0016852119060074
Le Pichon, X., Sea-floor spreading and continental drift, J. Geophys. Res., 1968, vol. 73, no. 12, pp. 3661-3705.

Lomakin, I.E. and Ivanov, V.E., The structural and tectonic position of the West Indian ridge and features of the geological structure, Geol. Polezn. Iskop. Mirovogo Okeana, 2012, no. 4, pp. 59-71.

Mahoney, J.J., Jones, W.B., Frey, F.A., Salters, V.J.M., Pyle, D.G., and Davies, H.L., Geochemical characteristics of lavas from broken ridge, the Naturaliste plateau and southernmost Kerguelen plateau: Cretaceous plateau volcanism in the Southeast Indian ocean, Chem. Geol., 1995, vol. 120, nos. 3-4, pp. 315-345.

Markl, R., Evidence for breakup of Eastern Gondwanaland by the early cretaceous, Nature, 1974, vol. 251, pp. 196200.

Masolov, V.N., Kurinin, R.G., and Grikorov, G.E., Crustal structure and tectonic significance of Antarctic rift zone from geophysical evidence, in Gondwana Five, Cresswell, M.M., Vella, P., and Balkema, A.A., Eds., Rotterdam, 1981, pp. 303-309.

Moeremans, R.E. and Singh, S.C., Seismic evidence of continental margin influence on the Ninety East Ridge in the Bay of Bengal, Geophys. Res. Lett., 2014, vol. 41, pp. 7143-7150.

Mohanty, S., Spatio-temporal evolution of the Satpura Mountain Belt of India: A comparison with the Capricorn Orogen of Western Australia and implication for evolution of the supercontinent Columbia, Geosci. Front., 2012, vol. 3, no. 3, pp. 241-267.

Montigny, R., Karpoff, A.M., and Hofmann, C., Résultats d'un dragage par $55^{\circ} 18^{\prime} \mathrm{S}-83^{\circ} 04^{\prime} \mathrm{N}$ dans le Bassin de Labuan (campagne MD 67, océan Indien méridional): Implications géodynamiques, J. Spec. Geosci. Mar., Soc. Geol. France, 1993, p. 83.

Mutter, J.C. and Cande, S.C., The early opening between Broken ridge and Kerguelen plateau, Mar. Geol., 1983, vol. 65, pp. 369-376.

Nougier, J., Contribution à l'étude géologique et géomorphologique des îles Kerguelen (Territoire des terres australes et antarctiques françaises), Comité national français des recherches antarctiques, 1969, no. 27.

Nougier, J. and Lameyre, J., The problem of the origin of the Plutonic rocks of the Kerguelen islands, Southern Indian ocean, EOS, Trans. Am. Geophys. Union, 1972 , vol. 53 , no. 4 , p. 547.

Operto, S. and Charvis, P., Kerguelen plateau: A volcanic passive margin fragment?, Geology, 1995, vol. 23, no. 2, pp. 137-140.

Operto, S. and Charvis, P., Deep structure of the Southern Kerguelen plateau (Southern Indian ocean) from ocean bottom seismometer wide-angle seismic data, J. Geophys. Res., 1996, vol. 101, no. 11, pp. 25077-25103.

Pavlenkova, N.I., The structure of the Earth's crust and upper mantle and global tectonics, in Spornye aspekty tektoniki plit $i$ vozmozhnye al'ternativy (Controversial Aspects of Plate Tectonics and Possible Alternatives), Sholpo, V.N., Ed., Moscow, 2002, pp. 64-83.

Ponthus, L., de Saint Blanquat, M., Guillaume, D., Le Romancer, M., Pearson, N., O’Reilly, S., and Grégoire, M., Plutonic processes in transitional oceanic plateau crust: Structure, age and emplacement of the South Rallier du 
Baty laccolith, Kerguelen islands, Terra Nova, 2020, vol. 32, no. 6, pp. 408-414.

Pronin, A.A., Geologicheskie problemy sovremennykh $i$ drevnikh okeanov (Geological Problems of Present and Ancient Oceans), Leningrad: Nauka, 1977.

Pushcharovskii, Yu.M. and Bezrukov, P.L., Tectonics of the Eastern Indian ocean, Geotektonika, 1973, no. 6, pp. 3-19.

Ramsay, D.C., Colwell, J.B., Coffin, M.F., Davies, H.L., Hill, P.J., Pigram, C.J., and Stagg, H.M.J., New findings from the Kerguelen plateau, Geology, 1986, vol. 14, pp. 589-593.

Recq, M. and Charvis, P., A seismic refraction survey in the Kerguelen isles, Southern Indian Ocean, Geophys. J. R. Astron. Soc., 1986, vol. 84, pp. 529-559.

Recq, M., Brefort, D., Malod, J., and Veinante, J., The Kerguelen isles (Southern Indian ocean): New results on deep structure from refraction profiles, Tectonophysics, 1990, vol. 182, pp. 227-248.

Ridd, M.F., South-East Asia as a part of Gondwanaland, Nature, 1971, vol. 234, pp. 531-533.

Roquet, F., Park, Y.H., Guinet, C., Bailleul, F., and Charrassin, J.B., Observations of the Fawn trough current over the Kerguelen plateau from instrumented elephant seals, J. Mar. Syst., 2009, vol. 78, pp. 377-393.

Salters, V.J.M., Storey, M., Sevigny, J.H., and Whitechurch, H., Trace element and isotopic characteristics of Kerguelen-Heard plateau basalts, in Proceedings of the Ocean Drilling Program, Scientific Results, Wise, S.W., Schlich, R., Jr., et al., Eds., 1992, vol. 120, p. 3.

Sastri, N.V., Venkatachala, B.S., and Narayanan, V., The evolution of the east coast of India, Palaeogeogr. Palaeoclimatol. Palaeoecol., 1981, vol. 36, pp. 23-54.

Schlich, R., Aseismic ridges, spreading centers and oceanic basins, in The Indian Ocean, New York: Plenum, 1983, vol. 6, pp. 51-147.

Schlich, R. and Patriat, P., Anomalies magnétiques de la branche Est de la dorsale medio-indienne entre les iles Amsterdam et Kerguelen, C. R. Acad. Sci., 1971, vol. 272.

Schlich, R. and Wise, S.W., Jr., The geologic and tectonic evolution of the Kerguelen plateau: An introduction to the scientific results of Leg 120, in Proceedings of the Ocean Drilling Program, Scientific Results, 1989, vol. 120, pp. 5-30.

Schlich, R., Delteil, J.R., Moulin, J., Patriat, P., and Guillaume, R., Mise en évidence d'une sèdimentation de marge continentale sur le plateau de Kerguelen-Heard, C. R. Hebd. Seances Acad. Sci., 1971.

Smith, A. and Hallem, A., The fit of the southern continents, Nature, 1970, vol. 225, pp. 139-144.
Stephenson, P.J., Some geological observations on Heard Island, in Antarctic Geology, Adie, R.J., Ed., Amsterdam: North-Holland, 1964, pp. 14-24.

Storey, M., Kent, R.W., Saunders, A.D., Salters, V.J., Hergt, J., Whitechurch, H., Sevigny, J.H., Thirlwall, M.F., Leat, P., Ghose, N.C., and Gifford, M., Lower Cretaceous volcanic rocks on continental margins and their relationship to the Kerguelen plateau, in Proceedings of the Ocean Drilling Program, Scientific Results, Wise, S.W., Schlich, R., Jr., et al., Eds., 1992, vol. 92, p. 2.

Udintsev, G.B., The expedition to the rift zone of the Indian Ocean on the Vityaz' (cruise no. 36), in Issledovaniya po probleme riftovykh zon Mirovogo okeana (Investigations on the Problem of Rift Zones of the World Ocean), Vinogradov, A.P. and Udintsev, G.B., Eds., Moscow: Nauka, 1972, vol. 1, p. 231.

Udintsev, G.B., Rel'ef $i$ stroenie dna okeanov (The Relief and Structure of Oceanic Floors), Moscow: Nedra, 1987.

Udintsev, G.B., Regional'naya geomorfologiya dna okeanov. Indiiskii okean (Regional Geomorphology of Oceanic Floors. The Indian Ocean), Moscow: Nauka, 1989.

Upton, B.G.J., Oceanic islands, in The Indian Ocean, New York: Plenum, 1983, vol. 6, pp. 585-648.

Vanney, J.R. and Johnson, G.L., Marine geomorphology of the Kerguelen-Antarctica passage (Southern Indian ocean), in The Ocean Floor, Scrutton, R. and Talwani, M., Eds., Chichester, UK: John Wiley and Sons, 1982, pp. 237-254.

Veevers, J.J., Powell, C.M., and Jonson, B.D., Greater India's palace in Gondwanaland and in Asia, Earth Planet. Sci. Lett., 1975, vol. 27, pp. 383-387.

Wallace, P., Frey, F., Weis, D., and Coffin, M., Origin and evolution of the Kerguelen plateau, Broken ridge and Kerguelen archipelago: Editorial, J. Petrol., 2002, vol. 43, no. 7, pp. 1105-1108.

Watkins, N.D., Gunn, B.M., Nougier, J., and Baksi, A.K., Kerguelen: Continental fragment or oceanic island?, Geol. Soc. Am. Bull., 1974, vol. 85, pp. 201-212.

Weis, D. and Frey, F.A., Submarine basalts of the Northern Kerguelen plateau: Interaction between the Kerguelen plume and the Southeast Indian ridge revealed at ODP site 1140, J. Petrol., 2002, vol. 43, no. 7, pp. 1287-1309.

Weis, D., Bassias, Y., Gautier, I., and Mennessier, J.-P., Dupal anomaly in existence 115 Ma ago: Evidence from isotopic study of the Kerguelen plateau (South Indian ocean), Geochim. Cosmochim. Acta, 1986, vol. 53, no. 8, pp. 2125-2131.

Wilson, J.T., Evidence from islands on the spreading of ocean floors, Nature, 1963, vol. 197, pp. 536-538.

Translated by M. Hannibal 